Ana Luiza Dias Batista

\title{
Um programa
}

Dissertação apresentada ao Programa de Pós-graduação em Artes Visuais, área de concentração Teoria, Ensino e Aprendizagem da Arte, linha de pesquisa História, Crítica e Teoria da Arte, da Escola de Comunicações e Artes da Universidade de São Paulo, como exigência parcial para obtenção do título de Mestre em Artes Visuais, sob a orientação da Profa. Dra. Sônia Salzstein Goldberg.

São Paulo

2008 
Ana Luiza Dias Batista

\section{Um programa}

Dissertação apresentada ao Programa de Pós-graduação em Artes Visuais, área de concentração Teoria, Ensino e Aprendizagem da Arte, linha de pesquisa História, Crítica e Teoria da Arte, da Escola de Comunicações e Artes da Universidade de São Paulo, como exigência parcial para obtenção do título de Mestre em Artes Visuais.

BANCA EXAMINADORA

Data de aprovação: 


\section{Agradecimentos}

\section{À Sônia Salzstein.}

Ao João Loureiro.

A Antônio Henrique Sobrinho, Antonio Paschoalique, Bruno Palazzo, Carla Zaccagnini, Chico Togni, Dulce Horta, Guy Amado, Laura Huzak Andreato, João Paulo Leite Guadanucci, Marcelo Berg, Mariana Lima, Miriam Biedermann, Nilton Célio, Nilton Ruiz, Rafael Xavier, Raquel Vendruscolo, Rodrigo Matheus, Sofia Borges, Tina Montenegro, Vítor César, Vítor Kisil.

Ao Departamento de Artes Plásticas da ECA-USP.

A Maria do Carmo, Mariana, Nildo, Silvia e Clara.

Aos amigos. 


\section{Resumo}

Esta pesquisa envolveu a realização de um trabalho de arte - o conjunto de vídeos intitulado "Programa" - e, paralelamente, de uma reflexão teórica. A reflexão tomou o "Programa" como objeto, procurando compreendê-lo, mas ela também constituiu instrumento do "Programa", conduzindo as formalizações. Ao dedicar-se à investigação da área de "Poéticas visuais", às dificuldades da reflexão sistemática sobre uma obra em andamento e às especificidades da fala do artista sobre o próprio trabalho, enunciou, para o trabalho que então se iniciava, as condições do contexto em que ele iria se produzir. Descrevendo um procedimento geral reincidente nos meus trabalhos, a reflexão apontou-lhe um repertório de operações. Ela foi movimento interno do "Programa" nas considerações sobre o campo que ele elegeu como objeto: as propagandas de televisão, e sobre aqueles que surgiram de modo incidental, como o vídeo. Também o foi na discussão de cada um dos esquetes - que foi esboçada antes da finalização do trabalho e orientou algumas últimas decisões. Depois do trabalho pronto, procurou-se rever e aprofundar os conceitos que vinham sendo utilizados, bem como submeter o "Programa" a uma apreciação mais distanciada.

Palavras-chave: artes visuais, arte contemporânea, poéticas visuais, audiovisual, vídeo. 


\begin{abstract}
This research involved the production of an art work - the set of videos entitled "Programa" [Program] - and, simultaneously, of a theoretic reflection. The reflection took the work as its object, trying to comprehend it, but it also constituted an instrument of this work, guiding its formalizations. The reflection was initially dedicated to the investigation of the postgraduate concentration area called "Visual poetics", as well as to the difficulties of a systematized conceptual apprehension of an ongoing art work and to the specificities of the artist's talks about his own work. In this manner it enunciated, for the work that was, then, getting started, the conditions of the context in which it would be produced. Describing a general procedure that was recurrent in the author's recent works, the reflection unveiled, to the new work, a repertoire of operations. The reflection was an internal movement of "Programa" while considering the field it had elected as its object: TV propaganda. This was also the case while considering those objects that appeared incidentally, such as the video. In the discussion of each one of the sketches - discussion that was outlined before the videos were finished - the reflection was also an internal movement as it oriented the last decisions. After the art work was finished, an attempt was made to review and deepen the concepts that had been used, as well as to submit "Programa" to a more distanced appreciation.
\end{abstract}

Key-words: visual arts, contemporary art, visual poetics, audiovisual, video. 


\section{Sumário}

1 "Programa" .07

2 Nota introdutória .08

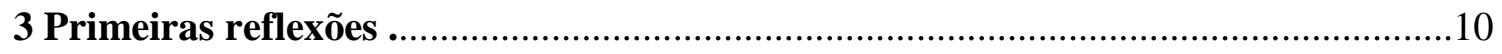

3.1 O mestrado em "Poéticas visuais" ................................................................10

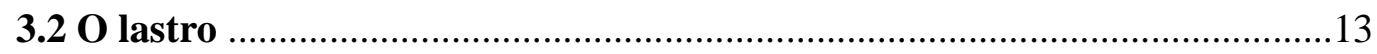

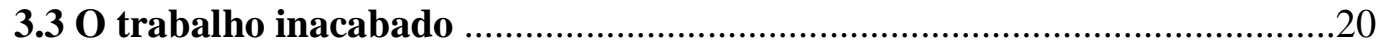

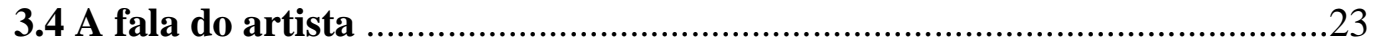

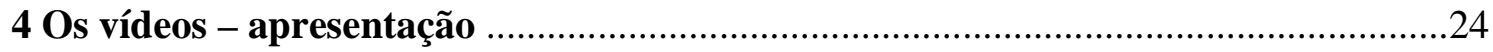

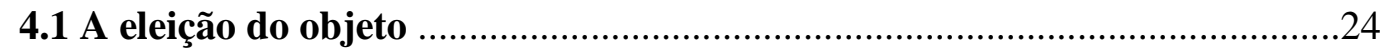

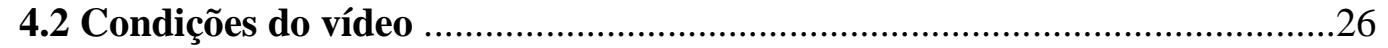

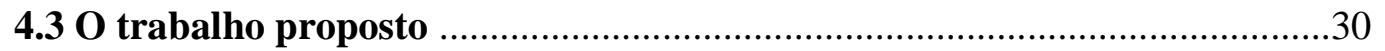

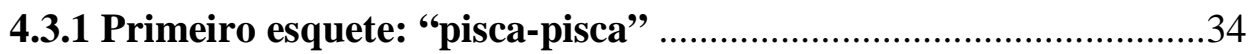

4.3.2 Segundo esquete: "jabuti”" ..............................................................36

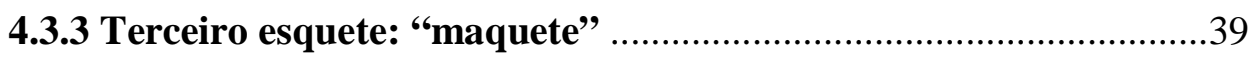

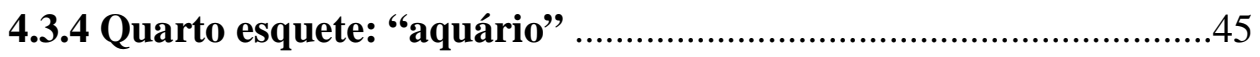

4.3.5 Quinto esquete: “ventilador” .....................................................49

4.3.6 Sexto esquete: "pisca-fade" .......................................................52

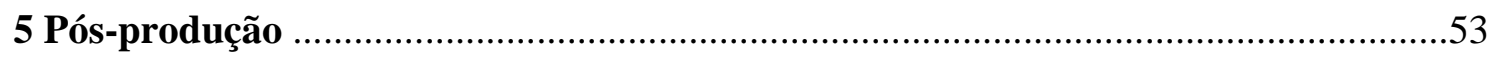

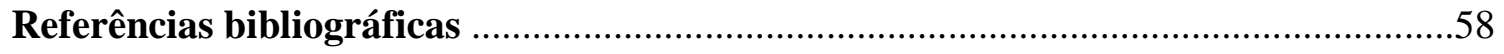




\section{1 "Programa"}

Assista ao DVD que acompanha este volume. 


\section{Nota introdutória}

O conjunto de pequenos vídeos intitulado "Programa" e a reflexão teórica apresentada neste texto resultaram da pesquisa de mestrado realizada no Departamento de Artes Plásticas da ECA-USP desde 2005. Grande parte do texto foi redigida paralelamente à concepção dos vídeos; assim, o fato de que eles ainda se encontravam inacabados, somado à minha condição de proximidade com eles, impôs dificuldades específicas à reflexão. Procuro, entretanto, me afastar de um discurso de intenções e levantar algumas questões que possam ser consideradas postas pelo "Programa" - e pelas etapas de seu processo de construção.

O texto apresenta o percurso conceitual que embasou as decisões nesse processo. Parto de uma rápida reflexão sobre as dissertações na área de "Poéticas visuais" defendidas na ECA$\mathrm{USP}^{1}$, que situou o contexto e enunciou uma série de problemas diante dos quais o trabalho deveria se posicionar. Em seguida, descrevo um procedimento geral que se repete em diferentes momentos da minha produção, apontando (para o leitor, mas também para o próprio trabalho que então se iniciava) o repertório de operações a partir do qual eu poderia me aproximar daquele contexto. Na descrição desse procedimento, optei por tentar apreendê-lo de modo abstrato, evitando recorrer diretamente a cada um de meus trabalhos anteriores e à singularidade de seus diferentes objetos. Dessa opção advém certa aridez nas passagens relativas à descrição do procedimento, aridez que reflete, acredito, uma opacidade que se manifesta nos trabalhos. É uma hipótese a ser testada.

A partir daí, são discutidas as principais questões que se apresentaram durante a construção do trabalho, entre as quais algumas cuja vigência se encerrou no processo, e que não necessariamente importam na apreensão do resultado. Elas estão incluídas neste texto porque informam retroativamente o procedimento geral e podem, por sua "ineficácia",

\footnotetext{
${ }^{1}$ Esta pesquisa de mestrado envolve a realização de um trabalho de arte acompanhado de reflexão teórica, dialogando diretamente com as dissertações defendidas na área de "Poéticas visuais". Ela foi apresentada à área de "Teoria, ensino e aprendizagem da arte", na linha de pesquisa "História, crítica e teoria da arte", porque eu pretendia concentrar esforços na compreensão do trabalho que se realizaria, procurando referências principalmente nas áreas de teoria da arte e filosofia. Ademais, pensei que seria possível identificar com mais clareza as limitações da fala do autor sobre o próprio trabalho se eu me posicionasse numa área externa àquela que usualmente acolhe os trabalhos de artistas. Ainda assim, esta pesquisa poderia ter sido apresentada a qualquer uma das duas áreas.
} 
esclarecer pontos abertos da discussão anterior. Também o respeito, no texto, à ordem efetiva de aproximação do trabalho com essas questões deve-se mais à intenção de pôr à prova aquele procedimento geral do que a uma valorização dos elementos do processo. Em seguida, cada um dos esquetes que compõem o "Programa" é descrito, tentando-se discutir suas operações e apontar referências pertinentes.

Assim, o texto a seguir constantemente conjuga dois movimentos de reflexão: um deles dedicado a compreender o novo trabalho (enquanto se realizava, mas também depois de sua finalização) e o outro a investigar os objetos que esse trabalho elegeu, fundamentando suas decisões. Os dois movimentos se conhecem e freqüentemente se confundem.

Apenas na última seção apresento exclusivamente idéias que surgiram a posteriori e se relacionam com o trabalho numa dimensão mais interpretativa. Essas idéias se distanciam do momento da produção e devem ser tomadas como tentativas de aproximação a um trabalho já emancipado, colocado no mundo. 


\section{Primeiras reflexões}

\subsection{O mestrado em "Poéticas visuais"}

"Poéticas visuais" é uma linha de pesquisa de limites imprecisos e diretrizes heterogêneas, e apresenta problemas que refletem a própria situação atual do meio artístico brasileiro, dentro e fora do ambiente universitário. Poder-se-ia alegar que a tensão central se deve à inadequação, às normas acadêmicas, de um conhecimento que se formaliza em construções particulares. De fato essa questão se coloca. Entretanto me parece que o problema se deve menos à impossibilidade de aceitação das especificidades do trabalho de arte pelos protocolos acadêmicos, e mais à ausência de questionamento dessas especificidades no interior dos próprios discursos dos artistas.

Nas etapas iniciais desta pesquisa, realizei uma consulta às dissertações em "Poéticas visuais" defendidas no Departamento de Artes Plásticas da ECA-USP, buscando identificar algumas recorrências e conhecer o contexto em que se inscreveria o trabalho a ser feito ${ }^{2}$.

Numa parcela dessas dissertações, o artista afirma a impossibilidade de seu trabalho ser apreendido pelo meio em que ali se apresenta; sua inadequação ao "modelo científico" com o qual identifica toda a produção acadêmica. Nelas, os autores nutrem profundo respeito por aquilo que não sabem sobre seus próprios trabalhos, como se conhecê-lo fosse fazer "secar suas fontes" ou, ainda, distraí-los de sua "tarefa primeira". Não há investimento intelectual no mestrado, basta-lhes mostrar o que já faziam. Desdenham das possibilidades do pensamento crítico em arte, sobretudo no ambiente universitário.

Outras se aventuram por uma descrição linear das obras produzidas desde o início da carreira, buscando aderir a idéias prontas para situar "confortavelmente" os trabalhos nos debates do momento. O corpo do texto é formado por um depoimento ilustrado das aventuras do artista, pontuado por conceitos em voga no meio de arte.

\footnotetext{
${ }^{2}$ O levantamento que proponho é bastante esquemático e, evidentemente, não faz justiça a todas as dissertações em "Poéticas visuais" defendidas no Departamento de Artes Plásticas da ECA-USP. Há exceções importantes.
} 
Há ainda as dissertações em que boa parte do texto é dedicada a um resumo da história da arte das últimas décadas, que culmina na produção do próprio autor. Elas não se furtam ao estudo e ao embate teórico com as questões colocadas pela produção histórica, entretanto permanecem, em geral, ligadas a uma concepção evolucionista da história da arte, na qual os fatos se encadeiam logicamente e conduzem a um grande final. A imposição de dialogar com a história da arte sobrecarrega o trabalho e acaba hipostasiando a indagação de suas próprias estratégias.

Uma quarta modalidade refere-se a projetos que se desenvolvem sem qualquer preocupação de fundamentação teórica, a partir de uma idéia de trabalho (artístico) previamente posta, dentro dos moldes da prática cotidiana do artista. São proposições concebidas e desenvolvidas durante o período do mestrado, sem, entretanto, terem se beneficiado dele em qualquer nível. A dissertação apresenta exaustiva documentação fotográfica e não se detém em questionamentos, aproveitando-se da apresentação de um produto "inédito" para se esquivar da reflexão.

Penso que o mestrado em "Poéticas visuais", como estágio inicial de aproximação à pesquisa, pode abrir mão de um inventário da produção anterior do artista. Sobretudo se pretende acolher artistas em início de carreira - e por início de carreira entendo exatamente o grau em que está, para a carreira acadêmica, um mestrando. Nesses casos, deve haver espaço para ações prospectivas, que evitem oferecer explicações precoces para um trabalho em formação e se dediquem a produzir um trabalho ou corpo de trabalhos, discutindo as questões que ele suscita e confrontando-as com referenciais teóricos.

Desse modo seria possível, também, evitar o caráter meramente reativo e pouco indagador da maioria das pesquisas acadêmicas em "Poéticas visuais" diante dos trabalhos artísticos realizados até aquela ocasião pelo mestrando. Elas passariam a constituir momentos no andamento da produção, momentos especiais por responder à exigência acadêmica de rigor e por oferecer-se de modo franco à discussão. Tornar-se-iam condições privilegiadas para a 
reflexão e realização dos trabalhos, impondo-lhes situações por vezes alheias à sua prática cotidiana e, justamente por isso, capazes de resultar em maior consciência dessa prática ${ }^{3}$.

O projeto apresentado aqui encontra motivação no caráter acadêmico para buscar uma experiência ao mesmo tempo nova (e portanto incerta) e significativa (com consciência do conjunto e poder de articulação) em relação aos trabalhos que já produzi ${ }^{4}$. Uma experiência em que se submetem concepções mais ou menos estáveis a uma espécie de teste de consistência, internalizando a tensão com o ambiente universitário através da problematização das próprias pretensões cognitivas do trabalho.

\footnotetext{
${ }^{3}$ Há que se aceitar que o engajamento em pesquisa acadêmica supõe um esforço específico. Isso vale para qualquer área. Não acho que o ritmo cotidiano de uma prática artística tenha que ser "respeitado". Mesmo porque esse ritmo é sempre contingente, e a crença em um fluxo natural no desenvolvimento da produção tem boa dose de auto-ilusão (ainda que, nas condições brasileiras, essa auto-ilusão seja, em parte, necessária).

4 "Quero dizer que não posso aderir à crença tradicional que postula um divórcio de natureza entre a objetividade do cientista e a subjetividade do escritor, como se um fosse dotado de uma 'liberdade' e o outro de uma 'vocação', ambas destinadas a escamotear ou sublimar os limites reais de sua situação". [BARTHES, R. Mitologias. Rio de Janeiro: Difel, 2003, p. 12].
} 


\subsection{O lastro}

O estabelecimento de um projeto de trabalho com essas características pressupõe, logo no princípio, um movimento arriscado: o artista tem que examinar retrospectivamente o trabalho para tentar encontrar-lhe um lastro nas diferentes manifestações.

Mas aquilo que liga os trabalhos realmente importa, ou é produto artificial do desejo de construção de uma identidade poética ${ }^{5}$ ? Tendo a duvidar desse lastro, pois dificilmente o artista poderá distinguir a experiência que se sedimenta nas diferentes manifestações do seu trabalho das ansiedades que poderiam conduzi-lo a uma ilusão retrospectiva. Sem o reconhecimento do lastro, entretanto, não há história - os trabalhos parecem exercícios perdidos, recomeçando sempre de um grau zero. Se não reivindicam uma articulação interna, eles são condenados à condição de casos particulares, incapazes de constituir uma história ${ }^{6}$. Então se está sempre fabricando uma noção de conjunto, tentando cercar o espaço de significação de cada trabalho e articulá-lo num sistema, ainda que frágil e necessariamente provisório. É preciso considerar, entretanto, que o caráter artificial e provisório desses sistemas não elimina sua capacidade de organização das idéias e orientação das pretensões dos trabalhos que se seguirão.

Os trabalhos que desenvolvo nos últimos anos são precedidos de uma série de considerações sobre os contextos em que se inscreverão. Os contextos podem ser os espaços onde os trabalhos serão exibidos, ou situações específicas a partir das quais eles deverão se produzir (como no presente caso, em que o contexto é o mestrado em artes visuais); esses contextos poderão ser "escolhidos", ou apresentarem-se de modo contingente. Suas

\footnotetext{
${ }^{5}$ Identidade que suporia um sujeito autoconsciente, em pleno controle até mesmo de suas inclinações subjetivas.

${ }^{6}$ A "história" possível não será uma cronologia que "remonta invariavelmente à inacessível origem”, mas se aproximará da disciplina a que Michel Foucault se dedica na Arqueologia do saber [São Paulo: Forense Universitária, 2004], definida como "uma certa maneira de dar status e elaboração a uma massa documental de que ela [a história] não se separa"; história cujo "problema não é mais a tradição e o rastro, mas o recorte e o limite; não é mais o fundamento que se perpetua, e sim as transformações que valem como fundação e renovação dos fundamentos" [p. 6-8].
} 
características físicas, históricas, simbólicas e, principalmente, ideológicas são levadas em conta.

A partir das características dos contextos, meus trabalhos elegem objetos variados, campos circunscritos de abordagem no mundo empírico ${ }^{7}$ - o comércio, carros, jardins, a decoração. O seu primeiro movimento é, portanto, um movimento de exteriorização: a referida eleição de objetos. Depois de tê-los eleito, os trabalhos procuram compreender suas manifestações particulares, suas condições de aparecimento social e cultural, seus usos, suas funções, sua história. Enumeram e organizam as suas características típicas e ressonâncias ideológicas, procurando apreender um código de funcionamento dos objetos. À medida que se aproximam desses objetos, os trabalhos se alinham a eles, apropriando-se mimeticamente de formas, procedimentos e regras de circulação ${ }^{8}$. Começam os embates materiais, e os trabalhos passam a acolher novos interesses e objetos - aos quais, mais uma vez, se alinham.

\footnotetext{
${ }^{7}$ O termo "objeto" aparecerá em minha reflexão quase sempre com essa acepção, ou seja, de um campo de abordagem que o trabalho circunscreve no mundo empírico. Pretende-se que esse sentido se esclareça no curso do texto. Por ora, é preciso notar que os objetos, diferentemente dos contextos, resultam necessariamente de escolhas deliberadas, de modo que sua determinação é já um primeiro movimento do trabalho. Quanto aos contextos, eles serão sempre considerados na eleição dos objetos, mas poderão, ou não, constituir material do trabalho. Nos casos em que os trabalhos mantêm os contextos "ativos", a relação desses contextos com os objetos é bastante determinante. Isso se dá, por exemplo, no "Plano Copan", trabalho realizado em parceria com dois outros artistas, descrito a seguir. Ali, o objeto "comércio" advinha diretamente do contexto da galeria comercial do edifício Copan, contexto que os artistas, por iniciativa própria, instituíram. Por sua vez, o "Programa", como se verá, conhece e responde ao contexto acadêmico, mas elege um objeto que não é dado imediatamente por esse contexto. A realização do trabalho, então, caminha sem que se remeta cada decisão novamente ao contexto.

${ }^{8}$ Esse alinhamento se dá por meio da evocação do código de funcionamento do objeto que fora enunciado conceitualmente, mas também através de movimentos de identificação e adesão às suas formas, procedimentos e regras de circulação, o que me permite sugerir que os trabalhos estabelecem laços de afinidade mimética com os objetos. A expressão é de Adorno, e designa uma potência cognitiva que escapa aos movimentos de abstração e categorização das representações do conceito (manifestação da razão instrumental), ou, antes, constitui um "resto" desses movimentos, sinalizando uma afinidade entre o conceito e o que lhe é heterogêneo, afinidade que o conceito, entretanto, rejeita. As operações miméticas centrais são a analogia, a similitude, a semelhança e a simpatia. Para Adorno, a mimese é a figura através da qual a arte se formula como autocrítica da razão, "identificando-se com a realidade social fetichizada". Cf. SAFATLE, Vladimir. A paixão do negativo: Lacan e a dialética. [São Paulo: UNESP, 2006, p. 305-315]. Para Adorno, no entanto, a mimese não constitui um momento do processo de criação das obras de arte, mas uma condição universal da própria arte, independente de suas pretensões realistas. Ela se impõe devido à própria condição de uma racionalidade particular que, ao "imitar", repõe, fora de si, os processos de dominação da razão instrumental; daí a possibilidade de fazer a (auto)crítica dessa razão. Vejamos alguns trechos da Teoria estética de Adorno [Lisboa: Edições 70, s/d]: “A arte objetiva o impulso mimético. Fixa-o
} 
A relação com os objetos, contudo, é peculiar, pois não há reciprocidade entre os termos: os objetos não reagem, permanecem sempre indiferentes às abordagens do trabalho. A eleição de objetos se relaciona, precisamente, com uma pergunta do trabalho sobre sua própria capacidade de se diferenciar, ou não, deles. O trabalho vai ao mundo, aproxima-se, ensaia objetividades e estabelece, no limite desse exercício, as condições de possibilidade de sua autonomia ${ }^{9}$.

Os trabalhos se aproximam dos objetos por meio de uma seqüência de operações que, ao final do processo, constitui uma metodologia de aproximação particular a cada um desses objetos. Com o termo "metodologia" não se pretende evocar a autoridade da tradição racionalista clássica e os critérios de clareza e distinção que orientam o progresso do pensamento em Descartes, por exemplo. Essa metodologia não é dada a priori; ela é inventada e demonstrada em cada um dos trabalhos, envolvendo o levantamento das formas típicas e dos códigos de funcionamento dos objetos eleitos, mas também o alinhamento mimético, e ainda a

e exterioriza-o na sua imediatidade, e também o nega. A imitação dos objetos tira de semelhante dialética da objetivação a conseqüência fatal. A realidade objetivada é o correlato da mimese objetivada. [...] Ao querer transformar-se num outro, semelhante ao objeto, a obra de arte torna-se dele dissemelhante. Só na autoalienação através da imitação é que o sujeito se fortifica de modo a sacudir o sortilégio da imitação" [p. 316317]. "A arte adere gestualmente à realidade apenas para, ao seu contato, virar-se convulsivamente para trás. [...] Semelhante comportamento aparenta-se ao mimético" [p. 317]. "A arte é comportamento mimético que, para sua objetivação, dispõe da mais avançada racionalidade - enquanto domínio do material e dos procedimentos técnicos. Com tal contradição, tal comportamento responde assim à contradição da própria ratio. [...] A oposição das obras de arte à dominação é mimese desta. Elas devem assemelhar-se ao comportamento dominador para produzir algo de qualitativamente diferente do mundo da dominação" [p. 320-321].

${ }^{9}$ O que está em questão é a possibilidade de existência do trabalho para além da condição de coisa entre coisas. A cada manifestação, ele corteja e, quando bem-sucedido, supera o risco de dissolução na vida. Ele não conta, de antemão, com um terreno privilegiado, com uma ontologia da arte. Deve se munir de estratégias para fundar esse terreno. A determinação de tais estratégias é um processo muito delicado. Não se trata de pretender aplicação direta no real; os trabalhos que o fazem costumam ser puramente cínicos, e, quando não, são de uma inocência que os dispõe à mais perversa instrumentalização. Ademais, ao supor-se "agente" no mundo empírico, a arte abdica do único dado que a define. Muitos trabalhos se beneficiam dessa confusão. Misturam-se à vida e negociam funções concretas, apenas para, ao ter que se submeter às regras da realidade e enfrentar sua indiferença, evocar apressadamente o estatuto do campo autônomo, a "liberdade" de objetivação do artista e uma série de argumentos que suas propostas a princípio rejeitavam. Se é possível aventar algo como uma "efetividade social da arte", acredito que só possa residir na sua autonomia, no modo com que a arte se distingue da realidade por uma formalização particular. Aí está a sua possibilidade mais radical de resistência. No meu trabalho, a formalização artística pode levar à distinção da realidade na medida em que reencena os significados que advêm dos seus objetos, levando a uma espécie de travamento. 
acolhida de interesses e objetos incidentais, o que resulta em diferentes abordagens. Daí a variedade do repertório formal dos trabalhos. À parte essa variedade e os motivos que determinam cada um deles individualmente, a explicitação da própria metodologia de aproximação aos objetos é uma característica reincidente; são as diferentes estratégias que os trabalhos assumem para aproximar-se do mundo que ganham forma. Assim, na sua experiência, não interessam os objetos propriamente ditos (por exemplo: o comércio, ou a decoração), mas, sim, a forma de acercar-se deles, os enquadramentos que o trabalho realiza.

No "Plano Copan" ${ }^{10}$, o comércio tornou-se objeto. Precisamente, o comércio que se desenvolveu no dito "centro novo" de São Paulo, a partir da década de 1950, nas galerias comerciais. Define-se o "mix de lojas"11 das galerias comerciais de acordo com um público a conquistar, cuja composição, por sua vez, é influenciada pelas instituições e estabelecimentos nas ruas próximas - pois as galerias, constituindo acessos transversais entre ruas, se beneficiam dos passantes. Nas vitrines, uma exigência particular: atrair num primeiro olhar, já que, diferentemente de um shopping center, as galerias comerciais não são destinações, são passagens.

Escolheu-se uma loja da galeria comercial do edifício Copan que possuía duas entradas; uma voltada para uma rua interna da galeria, outra para a fachada do prédio. Elevouse o piso da loja e construíram-se rampas dobráveis ${ }^{12}$ que convidavam os transeuntes a atravessá-la, encurtando o trajeto para a pequena galeria do edifício vizinho, que dá acesso à

\footnotetext{
${ }^{10}$ Trabalho realizado em parceria com Rodrigo Matheus e Eurico Lopes, através do projeto olho sp, no Edifício Copan, durante três meses do ano de 2002. Consistiu na abertura de uma loja na galeria comercial do edifício, a "Loja 48", na organização de uma "Exposição documental" no foyer e na instalação de um "Balcão de informações" junto ao acesso principal. As três situações cumpriam de fato as funções que seus nomes anunciam, ao mesmo tempo em que operavam dentro de uma lógica particular de relações internas.

${ }^{11}$ A expressão curiosa aparece em levantamentos estatísticos e estudos sociológicos recentes sobre as galerias comerciais que consultamos naquela ocasião. Trata-se, evidentemente, da distribuição de ramos nas lojas de um centro comercial.

${ }^{12} \mathrm{O}$ uso das rampas parte da averiguação de que um espaço torna-se mais "atraente" quando se apresentam obstruções e, em seguida, formas (cômodas) de solucioná-las. A rampa figura a facilitação do acesso, ainda que sua presença não responda a demandas funcionais. Além disso, ela intermedia uma transformação de escala entre o ambiente da galeria comercial do Copan e o ambiente do térreo da Loja 48, desdobrando-se para o exterior quando a loja está aberta, mas revelando ostensivamente dobradiças e manoplas. Assim como a rampa, vários outros recursos problematizavam sua funcionalidade.
} 
Avenida São Luís. As atividades comerciais ocorriam na sobreloja, de forma que o térreo da loja se apresentava como as próprias ruas internas das galerias: o acesso era livre e o passante não era "constrangido" pela presença de um vendedor. Ali, vitrines embutidas no piso e placas presas ao teto anunciavam os ramos contemplados: papelaria, consultoria imobiliária, artigos médicos e jogos.

Na sobreloja, cada um dos ramos - sem divisórias, separado dos demais pela descontinuidade do piso e do revestimento das paredes - expunha e vendia seus produtos segundo regras próprias. A papelaria continha apenas impressos, alguns dos quais antigos e fora de linha, vendidos a um preço fixo. Na seção de jogos, dispunham-se sobre uma bancada exemplares únicos de tabuleiros, fichas e cartelas. Quando um deles era vendido, conservavase seu espaço vazio. Os artigos médicos se limitavam a materiais descartáveis - rolos de algodão, ataduras, borrachas - e eram empilhados preenchendo integralmente as prateleiras de uma estante cirúrgica. A imobiliária, finalmente, fornecia indicações e informações sobre aluguel e compra de apartamentos exclusivamente no edifício Copan - e freqüentemente encaminhava o visitante a uma exposição no foyer onde ele podia ver, entre outras coisas, as plantas de todos os tipos de apartamento do edifício. Tratava-se da "Exposição documental", também ela concebida no limite de suas vocações usuais.

Assim, o trabalho se constrói através de um alinhamento ao objeto, tomando-lhe as formas, os procedimentos e as condições de aparecimento na realidade. Uma ambigüidade em relação à finalidade desse objeto - finalidade que, no trabalho, sempre se volta à evidenciação dos seus próprios critérios (tome-se por exemplo a rampa no "Plano Copan", tratada na nota 11) - permite a manipulação dos significados. Essa manipulação é da ordem de um travamento. A funcionalidade do objeto original é muitas vezes frustrada, aparecem regras particulares, insinua-se uma lógica interna.

Além disso, os códigos inicialmente enunciados de funcionamento do objeto nem sempre permanecem vigentes durante todo o processo de realização do trabalho. À medida que se iniciam as operações de alinhamento e os trabalhos adquirem materialidade, novos 
interesses e objetos se apresentam e são, ou não, acolhidos ${ }^{13}$. O que se formaliza é a própria metodologia de aproximação, os movimentos dos trabalhos em torno de objetos, em torno do mundo. Movimentos através dos quais os trabalhos repõem continuamente a indagação do seu próprio estatuto.

A eleição de um objeto a partir do contexto em que o trabalho se inscreve; o levantamento das formas típicas e dos códigos de funcionamento desse objeto; a construção de cada trabalho alinhada a essas formas e códigos; o deslocamento da finalidade; a alteração do estatuto dos objetos; o aparecimento da metodologia de aproximação como gesto de formalização - essas operações constituem um procedimento geral que configura, afinal, um lastro, ainda que, conforme espero ter deixado claro, esse lastro não deva restringir, ou, inversamente, afiançar os trabalhos futuros.

É preciso também mencionar que há no conjunto dos trabalhos outros aspectos recorrentes. Ainda que provisoriamente se prefira não associá-los ao lastro, dois desses aspectos são importantes e serão assinalados a seguir: o primeiro diz respeito a pontos comuns nos objetos eleitos; o segundo, a certa qualidade expressiva que se pode encontrar em todos os trabalhos.

Quanto aos objetos eleitos pelos trabalhos: a jardinagem, a decoração, o universo dos automóveis são campos da realidade social e cultural ligados a práticas universalizadas. Além disso, cada um desses campos revela uma gama variada de "tendências" internas, "tendências" ligadas a gostos, modelos culturais, identidades sociais, preferências de classes ${ }^{14}$. Essas

\footnotetext{
${ }^{13}$ Sobre os objetos, já vimos que eles surgem primeiramente de uma eleição: o trabalho circunscreve determinado campo de acordo com o contexto. O esforço é então conhecer esse campo. À medida que os levantamentos e enumerações dão lugar aos alinhamentos e assimilações, ou seja, à medida que caminha seu processo de construção e advêm os embates materiais, muitas vezes o estatuto do objeto original se modifica, se enfraquece, ele é deixado de lado. Objetos incidentais aparecem. A alteração do estatuto dos objetos durante a realização dos trabalhos será evidenciada na seção que dedico à apresentação do "Programa". É necessário, entretanto, esclarecer que aqueles objetos que permanecem postos e podem ser percebidos no resultado final não constituem o "conteúdo" do trabalho; em momento nenhum transcendem a posição de referentes. Os sentidos do trabalho resultam de formalizações que manipulam e travam os significados envolvidos nos objetos.

${ }^{14}$ Não é pretensão deste texto adentrar no debate da tradição marxista em torno da noção de classe. Penso, entretanto, que a categoria "classe", a despeito de sua insuficiência para dar conta das novas formas de
} 
“tendências" organizam estratos de identificação da população, alimentando, mas também criando, demandas de consumo. Ao incorporar internamente a estratificação, os campos constroem uma aparência de neutralidade ideológica: podem se associar diversos signos ao carro "esporte” ou aos móveis "clean”, mas é difícil reconhecer uma única linha ideológica no universo dos automóveis ou na decoração. Esses campos, naturalizados na vida contemporânea, contêm alguma promessa de felicidade, promessa que se funda justamente na diversidade de suas "tendências" e no seu apelo universal. Sabe-se que essa diversidade, no entanto, acaba reduzida a um ponto médio, uma vez que as opções mais extremas sempre encontram equivalentes no pólo oposto, anulando-se reciprocamente. $\mathrm{O}$ fato de os consumidores oscilarem livremente na escala das tendências atesta a equivalência delas. A noção um tanto abstrata de uma experiência média do mundo, experiência rebaixada na qual a diversidade das "tendências" aparece em estado de saturação, se impôs naturalmente.

O trabalho aborda esses objetos com operações de baixa complexidade, tecnologias e materiais corriqueiros e formalizações austeras - formalizações que se apresentam no limite da indiferenciação, por muito pouco não se integrando aos objetos. As soluções são econômicas, "limpas", e todos os elementos remetem ao todo, reafirmando constantemente sua necessidade. Entretanto nada aparece em estado cru: é por um tratamento meticuloso dos materiais que eles se tornam capazes de evocar sua existência ordinária. Uma condição ostensivamente controlada permite que assumam formas austeras.

aglutinação corporativa nos tempos da globalização, conserva um poder explicativo nesta argumentação, ao designar uma concatenação de modos de vida que produz modelos de comportamentos e aspirações. 


\subsection{O trabalho inacabado}

Vimos que um projeto de trabalho plástico, especialmente no âmbito acadêmico, enfrenta de saída as dificuldades enumeradas no início da seção "O lastro", dificuldades que se referem à necessidade de esboçar um sistema para articular a produção anterior, a despeito do alto grau de arbitrariedade e da vigência provisória desse sistema. Mas outras dificuldades se apresentam ao trabalho quando, ainda inacabado, torna-se objeto de uma reflexão teórica sistemática do $\operatorname{artista}^{15}$. O trabalho se desenvolve paralelamente a essa reflexão e os referenciais "externos" evocados para a sua compreensão são internalizados, passando a desempenhar papéis mais ou menos diretos no próprio processo de produção.

Assim ocorreu, por exemplo, com as referências ao cinema nas reflexões sobre o "Programa". Consultei alguns textos de crítica e teoria do cinema com o objetivo inicial de me familiarizar com um vocabulário e alguns conceitos que permitissem descrever corretamente o trabalho que estava realizando, uma vez que se tratava de um conjunto de vídeos. Descrever o trabalho seria um primeiro movimento para compreendê-lo. Esses textos, entretanto, despertaram interesses novos: em primeiro lugar, os textos remetiam aos filmes, e ambos informavam ao trabalho um repertório de recursos e operações próprios ao meio; além disso, a noção, ainda que parcial, de uma história das produções audiovisuais possibilitava avaliar as condições de emergência e as filiações ideológicas desses recursos e operações ${ }^{16}$. O "Programa" se apropriou de alguns deles ${ }^{17}$.

\footnotetext{
${ }^{15}$ Deve-se considerar que, assim como todo novo trabalho exige um redimensionamento do conjunto que o precede, também será sempre acompanhado de um movimento de autocompreensão. As exigências acadêmicas, ao menos como formuladas nesta pesquisa, apenas asseveram essas dificuldades, sugerindo maior esforço de articulação do trabalho novo à produção anterior do artista no primeiro caso e maior esforço de sistematização da reflexão teórica no segundo.

${ }^{16}$ Note-se que não se procurou situar o "Programa" na história das produções audiovisuais - como de resto tampouco se tentou situá-lo na própria história da arte. Tanto uma quanto a outra não constituíram propriamente um lugar para o trabalho, mas ofereceram-lhe fontes e referências.

${ }^{17}$ As idéias para o esquete apelidado de "maquete", que será descrito numa seção posterior do texto, surgiram do estudo das relações entre som e imagem em dois momentos precisos da história do cinema: na passagem para o cinema sonoro, em fins da década de 1920, e na consolidação de um conjunto de regras pelas grandes produções hollywoodianas dos anos 1970. Alguns recursos de transição da decupagem clássica, por sua vez, são citados no esquete apelidado de "pisca-fade", por exemplo.
} 
Já sabíamos que a reflexão era gesto constitutivo do trabalho, ao permitir, de acordo com o procedimento geral descrito há pouco, a compreensão do funcionamento dos objetos que ele elege no mundo. Nesse sentido, a reflexão sobre o cinema, completamente incidental, aliou-se à reflexão sobre os objetos eleitos pelo "Programa" na condução das formalizações do trabalho, sendo submetida constantemente ao teste da prática ${ }^{18}$. Mas na aproximação com o cinema ocorreu algo mais: os bons filmes e os bons textos que pude conhecer tiveram impacto sobre a própria formação do trabalho, sobre a qualidade do seu pensamento (se pudermos concordar que o trabalho tem um "pensamento" próprio), o que poderá ou não já aparecer no "Programa", mas certamente se manifestará nos meus trabalhos futuros.

Ainda um outro risco se impõe em face das exigências de reflexão sistemática do artista no contexto acadêmico: trazer-se para o trabalho questões que não lhe dizem respeito, forçando conexões em pontos cuja abertura era importante, e mesmo necessária, para o seu desenvolvimento. Assim, estabelece-se uma obrigação de correspondência precisa entre o projeto e o resultado, de transparência total do processo, desconsiderando-se que é sobretudo dos momentos de opacidade que surgem os sentidos novos. Acredito que, no que o artista não pode enunciar durante o processo, no que resiste às suas intenções conscientes, reside uma potência $^{19}$. O trabalho só pode ser apreendido em todos os seus sentidos quando finalizado;

\footnotetext{
${ }^{18}$ Isso permite aventar que a reflexão, no interior do trabalho, possui algo de uma técnica. Adorno inicia algumas considerações sobre a técnica na Teoria estética definindo-a como "o nome estético para o domínio material”. Aplicando-se a noção de técnica a uma série de operações mentais não se ignora esse sentido; pretende-se, justamente, indicar a concretude dessas operações no processo de trabalho. Mas Adorno submete o tal "nome estético" que designaria o "domínio material" a torções que podem ser, aqui, significativas: "Na arte, o limiar entre o artesanato e a técnica não é, como na produção material, uma estrita quantificação dos procedimentos incompatível com o telos qualitativo; também não é a introdução de máquinas, mas antes a preponderância de uma livre disposição dos meios pela consciência [...]. Perante o conteúdo, o aspecto técnico é apenas um entre outros; não há nenhuma obra de arte que seja apenas a totalidade dos seus momentos técnicos. [...] A técnica possui caráter de chave para o conhecimento da arte; só ela conduz a reflexão para o interior das obras; certamente, só possui aquele que fala a sua linguagem. Porque o conteúdo não é um elemento fabricado pelo homem, a técnica não abarca o todo da arte; o conteúdo deve unicamente extrapolar-se a partir da sua concreção. A técnica é a figura determinável do enigma das obras de arte, figura ao mesmo tempo racional e abstrata. Ela autoriza o juízo na zona do que é desprovido de juízo. [...] Seria agradável ao hábito vulgar eliminá-la; mas seria falso, porque a técnica é constituída pelos seus problemas, pela tarefa aporética que essa obra se põe objetivamente." [Op. cit., p. 240-241].

${ }^{19}$ Essa constatação, entretanto, não pode legitimar uma abdicação de se compreender o que se faz. Ao menos no caso do meu trabalho, posso afirmar com segurança que quanto maior o empenho de compreensão, quanto mais eu "enuncio", mais eloqüente é o que resiste.
} 
apenas aí se evidencia a sedimentação dos conteúdos numa determinada forma ${ }^{20}$. Uma reflexão que se dê durante o processo de produção do trabalho deverá conhecer esse limite.

Em conseqüência, o que se tenta efetivar aqui, a compreensão de um trabalho inacabado, terá de se realizar a contrapelo de uma desconfiança em relação à autoridade da própria reflexão, ao mesmo tempo em que terá de lidar com um constante processo de internalização das referências "externas".

\footnotetext{
${ }^{20}$ A referência aqui é mais uma vez Adorno - "A arte só é interpretável pela lei do seu movimento [...]. O caráter artístico específico que nela existe deve deduzir-se, quanto ao conteúdo, do seu Outro [...]. Ela especifica-se ao separar-se daquilo por que tomou forma; a sua lei de movimento constitui a sua própria lei formal" [Op. cit., p. 13].
} 


\subsection{A fala do artista}

Um segundo aspecto que influencia o empenho de reflexão do artista sobre a própria obra é o problema da imprecisão dos limites entre uma instância de indagação dos trabalhos que é essencialmente privada e os sentidos que se evidenciam quando esses trabalhos aparecem publicamente.

Por mais que o artista seja capaz de uma disciplina intelectual de distanciamento em relação ao trabalho, a sua compreensão será sempre mediada pelas intenções (reconhecidas ou não como tais) envolvidas no processo de produção. Assim, o risco que se apresenta ao texto teórico de artista é confundir as questões postas pelo trabalho com as intenções do artista, transformando aquilo que se pretendia uma discussão do trabalho em inventário de intenções, ou, ainda, se o exercício for mais rigoroso, em confrontação dessas intenções com o resultado final; levantamento dos sucessos e insucessos na transcrição das "idéias". De qualquer modo, a princípio, o artista terá dificuldades para lidar com o trabalho como "ente autônomo", terá dificuldades para perceber os sentidos que se estabelecem em suas relações com o mundo, terá dificuldades para diferenciar o discurso do trabalho do seu próprio discurso.

Por outro lado, acredito que justamente dessas dificuldades pode advir a especificidade da fala do artista. Essa fala não pleiteará o provável distanciamento do discurso do crítico, ou a pretensa objetividade do texto científico, mas tampouco precisa recusar indagações teóricas. Se o artista se dispuser a um enfrentamento franco, gozará de condições privilegiadas para formular, a partir mesmo de sua posição inevitavelmente parcial, hipóteses sobre o estatuto da própria arte, suas possibilidades cognitivas. 


\section{Os vídeos - apresentação}

\subsection{A eleição do objeto}

Seguindo o procedimento geral que descrevi anteriormente ${ }^{21}$, e tendo em conta as questões que, a partir das minhas reflexões sobre o mestrado em "Poéticas visuais", pareciam pesar sobre um projeto de artista no meio acadêmico (exigência de rigor, relevância do debate, mas também alguma capacidade auto-reflexiva do trabalho de arte a ser apresentado, um vínculo forte com o conjunto da produção anterior), elegi o campo da publicidade, mais especificamente o das propagandas de televisão, como objeto do trabalho.

Eu procurava um objeto cuja lógica estivesse de certa forma implicada nos meus trabalhos anteriores, e cuja exploração pudesse, assim, dizer-lhes respeito. A propaganda, sendo talvez a maior figura daquela experiência média do mundo a que aludi em outra seção deste texto, não apenas organiza estratos internos de identificação da população (oferecendo "tendências" diversificadas), mas se expande, impregnando todos os outros campos com seus códigos de funcionamento. Esses códigos já haviam se explicitado em minha produção anterior. De resto, a propaganda constitui um domínio reconhecível a despeito da variedade infinita - de seus assuntos (produtos) e de suas abordagens (estratégias), tal como meu trabalho.

Tomando como parâmetro o intervalo comercial televisivo, obtinha um conjunto de unidades autônomas - cada propaganda tem um conteúdo particular, um produto sendo anunciado, uma narrativa que se inicia, evolui e se encerra dentro de seu espaço restrito. Essas unidades são aparentadas (1) por um contorno comum (forma-filme, regra de circulação, duração), (2) uma série de recorrências formais (as convenções de representação do meio) e (3) uma mesma finalidade (o incentivo ao consumo). À parte esses fatores, cada unidade

\footnotetext{
${ }^{21}$ Refiro-me a uma série de operações que vêm se repetindo nos meus trabalhos recentes: a eleição de um objeto a partir do contexto em que o trabalho se inscreve; o levantamento das formas típicas e dos códigos de funcionamento desse objeto; a construção de cada trabalho alinhada a essas formas e códigos; o deslocamento da finalidade; a alteração do estatuto dos objetos e o aparecimento da metodologia de aproximação como gesto de formalização.
} 
pretende destacar-se o máximo possível das demais, sobressair, fixar-se na memória dos espectadores.

Desse modo, instaura-se uma aparente concorrência entre cada uma das propagandas de um mesmo intervalo, ainda que os ramos comerciais não sejam coincidentes. É uma concorrência pela atenção do espectador/ consumidor, em que se insere um curioso critério de diferença. Curioso porque, sendo a concorrência aparente (nota-se que há, de fato, solidariedade entre as propagandas), a diferença também não é real; trata-se antes de um uso diversificado de estratégias de visibilidade. O consumidor, entretanto, não é logrado; ele adere à ficção da singularidade (singularidade dos produtos e das propagandas; singularidade de sua própria subjetividade explicitada nas faixas de consumo).

A propaganda incorpora com rapidez qualquer procedimento ao seu repertório, na urgência por se fazer ver em um meio regido pelo critério da "surpresa",22. Mesmo a metacrítica - a propaganda citando, "distanciada", os lugares-comuns da propaganda, por exemplo - torna-se instrumento de ampliação de sua visibilidade (e da de seus produtos). Essa capacidade de incorporação universal, entretanto, não leva as propagandas - não porque lhes falte competência, mas porque não é seu objetivo - a transcender os limites de uma experiência média, confortável, de único tom. A incorporação é, justamente, incorporação de dados ao repertório médio, que, inflado, simula admitir posições extremas.

Além disso, a projeção sucessiva e a repetição das mesmas propagandas nos diferentes intervalos acabam por levar ao fastio. Esse fastio se relaciona com a própria decantação da experiência média e não desperta resistência ou posturas críticas no público das propagandas porque é constantemente sublimado pela reiteração do "contrato ficcional" de aceitação da diferença.

\footnotetext{
${ }^{22}$ Diversificam-se os padrões de simulação da diferença qualitativa, diferença que é rapidamente convertida à catalogação de estratos quantitativos. As propagandas comportam-se como os produtos que anunciam mecanicamente diferenciados ainda que efetivamente semelhantes; elas devem, em primeiro lugar, vender a si mesmas, vender sua própria capacidade de surpreender.
} 


\subsection{Condições do vídeo}

Definido o primeiro objeto, estabeleceu-se o meio a ser utilizado na construção do trabalho: o vídeo. O vídeo tem, como se sabe, parentesco com os meios em que se realizam as propagandas televisivas (em geral filmadas em película, mas formatadas para exibição em aparelhos de televisão). Um alinhamento formal entre o trabalho e o campo que ele elege como objeto é adequado àquele procedimento geral - afinal, o trabalho se formaliza a partir dos movimentos de aproximação aos objetos, movimentos que ele realiza sem ter ainda estabelecido a sua diferença. Resta, portanto, entender por que se escolheu o vídeo e não quaisquer dos meios usuais de produção das propagandas, ou seja, apontar as características particulares do vídeo que motivaram a decisão.

Em primeiro lugar, é preciso esclarecer que o vídeo, neste trabalho, a despeito da deliberação seca sugerida no parágrafo anterior, não é simples "mídia"23. Ele é um objeto, um campo que o trabalho circunscreve e aborda devido ao lugar que adquiriu na experiência média dos indivíduos. As vinhetas das emissoras de televisão, o registro dos eventos familiares, o testemunho pessoal (nos sites de relacionamento, nas pesquisas de opinião), a captação anônima dos acontecimentos de "interesse público" no calor da hora, as imagens de vida privada obtidas ou divulgadas sem autorização, o merchandising corporativo etc. preenchem toda uma gama de "tendências".

\footnotetext{
${ }^{23}$ Evidentemente se espera que os "meios", na arte, excedam uma dimensão instrumental. Os trabalhos de arte (mesmo aqueles que, como o meu, não permanecem fiéis a uma única linguagem em suas diferentes manifestações), quaisquer que sejam seus outros "assuntos", e quaisquer que sejam as relações que estabelecem com a presença de assuntos, tratariam sempre de sua própria linguagem; seriam, de algum modo, auto-reflexivos. Em diferentes formulações teóricas na modernidade esta foi, inclusive, considerada uma especificidade capaz de garantir a autonomia da arte. Aqui, entretanto, procuro não tomar de antemão idéias que, por mais que possam parecer ponto pacífico e encontrar ressonância se aplicadas a este trabalho, partem de premissas do que seja a arte. O esforço do trabalho é refazer constantemente essa pergunta, de modo que a decisão de abordar o vídeo como um objeto, antes de considerá-lo sob a perspectiva da "linguagem", revela a vontade de devolvê-lo à condição de coisa entre coisas, e entendê-lo assim. Isso não quer dizer que o trabalho se pretenda fora da história da arte, ou que ele abdique da noção de linguagem, ou que ele recuse à arte uma dimensão ontológica. Tomar, a princípio, o meio em que se produzirá o trabalho como "coisa entre coisas" é movimento estratégico do processo, que impõe conseqüências às formalizações mas não impede que esse trabalho, uma vez pronto, reivindique para o vídeo um estatuto de linguagem.
} 
Além disso, atualmente já não se costuma associar o vídeo a uma tecnologia complexa, cujo domínio exigiria dedicação e aperfeiçoamento. Como de praxe, o fascínio tecnológico que aliava à produção em vídeo um (perverso) signo de poder - dá lugar a um primeiro estágio de acomodação - em que, numa apropriação generalizada, se dissolve o signo de poder, mas também a consciência das mediações. Com a universalização do vídeo surge, então, uma suposta neutralidade, uma condição rebaixada que é comum, de resto, aos objetos usuais dos meus trabalhos recentes, como vimos.

Sobre esse objeto o trabalho se debruça em busca de especificidades com as quais, mais uma vez, se alinhará. Acredito que as principais qualidades que lhe interessam, e que ele, de certa forma, mimetiza, são justamente o tom familiar e a expressão de acessibilidade que o vídeo manifesta nos dias atuais, a "leveza" e a "naturalidade" que advêm de sua ocorrência dispersa nos mais diferentes setores da vida - qualidades que agregam um critério de imediatidade à felicidade que os campos eleitos pelos meus trabalhos costumavam prometer.

\section{É preciso notar que os vários discursos sobre o vídeo que se apresentam na literatura} especializada, ou no meio das artes visuais, não estão diretamente em questão para este trabalho ${ }^{24}$. $\mathrm{O}$ vídeo de que ele trata é aquele incorporado às práticas sociais comuns. Como foi

\footnotetext{
${ }^{24}$ Dos discursos sobre o vídeo no meio das artes visuais, eu destacaria quatro, todos eles distantes dos interesses e posições deste trabalho: (1) como aparato capaz de guardar e reproduzir aquilo que um sujeito vê. A densidade psicológica desse sujeito, as qualidades particulares de seu olhar se cristalizam numa densidade da imagem. Como se sabe, "plano subjetivo", no vocabulário cinematográfico, designa um plano visto "pelos olhos de um personagem". No cinema narrativo clássico trata-se, em geral, de um recurso para conquistar a adesão do espectador, através do qual ele é levado literalmente para dentro da narrativa (seu olhar coincidindo com o de um personagem). Neste caso, o recurso reaparece com pretensão de transparência ainda maior do que a do cinema clássico: não há "personagem", o sujeito com o qual o espectador se identifica é pessoa "real". (2) Como exploração de uma tecnologia capaz de gerar uma imagem nova, "híbrida". O interesse está nas aberturas que essa novidade traria, para além dos âmbitos esquadrinhados da existência. Valorizam-se as especificidades das imagens eletrônicas, evocando-se critérios como "criatividade" e "caos" para se opor às normas hegemônicas de produção da imagem nas mídias de massa, e se advoga em favor do entrecruzamento entre arte, ciência e tecnologia. Consideram-se fundamentalmente vocações contrárias à figuração: "E quanto mais o produto obtido manifesta consciência dos meios com os quais se constrói, quanto mais criativos e desbravadores são os resultados, mais o espaço representado se mostra como 'irreal', mais esboroam as categorias da referencialidade e se caminha ao rumo contrário da figuração. Liberada da fatalidade figurativa, a arte do vídeo torna-se cada vez menos naturalista e cada vez mais gráfica ou conceitual. [...] A grande virtude da imagem granulosa e saturada do vídeo é corroer essa visão inocente que ainda embala os sistemas figurativos convencionais, segundo a qual o mundo nos pode ser revelado através deles". [MACHADO, Arlindo. Hegemonia da imagem eletrônica. In: Máquina e imaginário: o desafio das poéticas tecnológicas. São Paulo: EDUSP, 1993, p. 52-54]. (3) Como
} 
mencionado acima, o vídeo não interessa ao trabalho como "linguagem artística", mas como mídia que suporta pacificamente as mais diferentes manifestações; não como novidade, mas como prática universalizada.

O trabalho procura enumerar alguns recursos que o vídeo, na sua disponibilidade universal, geralmente usa para ocultar a condição de mediação ativa do olhar. Interessa-se por sua mecânica de comunicação de sentidos, no momento mesmo em que essa mecânica se torna aparentemente imperceptível. Em tempos de festa em torno das possibilidades "emancipatórias" do uso autobiográfico e testemunhal dos meios de comunicação, a revelação do aparato - que, como se verá, é questão central para o trabalho - torna-se recolocação da mediação; resistência à "sinceridade" envolvida na celebração da democratização do acesso, na celebração do olhar subjetivamente eloqüente etc. Tal recolocação da mediação se dá por uma reconversão do vídeo à opacidade; neste trabalho, não se verá um mundo diegético íntegro através do vídeo, muito menos a realidade documentada. Não haverá anterioridade, seja como efeito armado para a identificação do espectador com o mundo ficcional, seja como condição da vida real (que, obviamente, preexiste aos momentos da captação). Tudo será explicitamente posto para a câmera, quando não por ela; o "Programa" - assim ele se intitulará - será ostensivamente produto de estúdio.

Mas, principalmente, não se verá a imagem na sua textura abstrata. O trabalho não se preocupa com as potencialidades da imagem videográfica, as especulações visuais de que só ela seria capaz, as transformações em relação à tradição e aos métodos do cinema - a espessura $^{25}$ que substituiria a profundidade de campo dos planos cinematográficos, suprimindo a escala de imagens do primeiro plano ao fundo; a eliminação do espaço off, que daria lugar a uma espécie de presença integral em que tudo se mostra ao mesmo tempo; a tendência à

mídia libertária, na qual se anula a hierarquia nas relações entre produtor e receptor. O vídeo traria consigo a promessa de democratização do acesso à arte, podendo realizar uma tarefa que, no começo do século passado, se atribuía ao cinema [Cf. BENJAMIN, Walter. A obra de arte na era de sua reprodutibilidade técnica. In: Obras escolhidas: magia e técnica, arte e política. São Paulo: Brasiliense, 1994]. (4) Como registro de uma ação. $\mathrm{O}$ vídeo deve ser capaz de capturar integralmente um acontecimento externo, reatualizando-o sem perda sempre que exibido. Esse uso se liga a outras manifestações artísticas, como happenings e performances.

${ }^{25}$ A expressão é de Philippe Dubois. [Cinema, vídeo, Godard. São Paulo: CosacNaify, 2004]. 
fragmentação e à colagem etc. Não interessam ao trabalho as qualidades formais a partir das quais se reivindica uma natureza particular para a imagem videográfica, mas a condição de “coisa entre coisas" que permite a circulação universal dessas imagens na vida contemporânea. Não há pretensão de experimentação de linguagem, mas um uso elementar de recursos básicos. 


\subsection{O trabalho proposto}

Propus a realização de um conjunto de seis vídeos curtos montados em ordem determinada, com cortes secos, cada qual funcionando como unidade autônoma, com começo, meio e fim definidos e conteúdos próprios ${ }^{26}$. A princípio, previa eleger esses conteúdos a partir de um levantamento das estratégias convencionais das propagandas televisivas, possivelmente remetendo a um produto ou estabelecimento específico, mas, à medida que o trabalho vai se desenvolvendo, os resultados mostram-se mais relacionados a outras questões, sobretudo à questão mais ampla das formas de dar a ver, de exibir, de enunciar visualmente, abandonando o vínculo explícito com as propagandas.

As formas de 'dar a ver' aparecem no trabalho através da tematização de recursos utilizados para atrair a atenção do olhar, sendo esses recursos muitas vezes desvinculados dos conteúdos para os quais se deseja apontar: mangueiras de luz, varais de fitas metálicas, placas, bases em movimento. Trata-se de elementos de mediação, nos quais o olhar não se demora; objetos transitivos. Destes, o trabalho não se limitou a abordar os recursos usados no interior das propagandas de televisão ${ }^{27}$. Com exceção do quarto esquete (que apelidei de "aquário"28),

\footnotetext{
${ }^{26}$ Considerei característica interessante o fato de que o trabalho prático realizado para o mestrado, sendo um conjunto de vídeos, não ocorreria num tempo e lugar determinados, mas poderia acompanhar a dissertação, tornando-se presente a cada exibição. O tipo específico de aproximação ao vídeo que se realizou, ademais, garante que essa condição variável de espaço e tempo não se construa através da segregação entre o espaçotempo da tela e o espaço-tempo "real" do espectador - lembrando o comentário de Ismail Xavier sobre as reflexões de Bela Balazs e, mais tarde, de Christian Metz em torno da experiência do cinema [XAVIER, I. O discurso cinematográfico: a opacidade e a transparência. $3^{\mathrm{a}}$ edição. São Paulo: Paz e Terra, 2005, p. 2223.]. O trabalho se alinha ao vídeo como "coisa no mundo", o que envolve necessariamente o próprio ato de assistir. Os acontecimentos que se vêem na tela reivindicam efetividade sobre a situação física do espectador. Esses acontecimentos, como se perceberá, remetem incessantemente não apenas às condições concretas da captação, mas também às da exibição.

Porque o "Programa", embora resulte da pesquisa de mestrado, é um trabalho de arte, ele deve também prever suas condições de circulação para além do contexto acadêmico, no meio das artes visuais. Defini que, nas situações de exposição, ele deverá ser apresentado, em loop, num aparelho de televisão de 29 polegadas (por motivos que serão explicitados na descrição do primeiro esquete) em uma sala de espera. Assim ele se alinha ainda mais aos seus objetos, fortalecendo a referência ao intervalo comercial e, principalmente, solicitando um tipo particular de relação do espectador.

${ }^{27}$ A afinidade desses recursos com as propagandas de televisão é menos interna, no sentido de pertencerem ao repertório das propagandas, e mais estrutural: as próprias propagandas são recursos dessa ordem; chamam a atenção através de qualidades e estratégias que, a princípio, não precisam dizer respeito ao produto anunciado; devem se "diversificar".
} 
que remete diretamente a uma forma já apropriada pelas propagandas, os recursos eleitos têm uso corrente em espaços urbanos; fachadas de estabelecimentos comerciais, interiores de vitrines. Quando filmados, evidenciam sua "ausência de conteúdo", sua relação com a visibilidade de algo que lhes transcende e que, ali, não se concretiza, a não ser na revelação do próprio aparato.

A revelação do aparato é, de fato, questão recorrente. A câmera muitas vezes mimetiza o comportamento dos objetos filmados e vice-versa. O próprio vídeo é tomado como forma de enunciação visual, tendo seu funcionamento constantemente explicitado. Assim, no esquete apelidado de "ventilador", os dois aparelhos (câmera e ventilador) se identificam, não apenas na subordinação funcional aos varais de fita metálica - o ventilador está ali para dar-lhes movimento, a câmera para dar-lhes visibilidade, ambos tentando reproduzir artificialmente suas condições de existência externa -, mas no próprio movimento que realizam. A câmera, a princípio fixa, passa a mover-se junto com o ventilador, imitando suas oscilações. No "jabuti”, o passo do zoom out é dado pelo deslocamento do bicho. Na "maquete", a diminuição gradual do número de sons a cada volta de uma base mecânica diante da câmera fixa alude ao procedimento artificial de construção de verossimilhança em espaços filmados. No "aquário", o movimento do cardume é virtualmente obtido pela sucessão de imagens fixas, remetendo aos fotogramas de um filme ${ }^{29}$. No último esquete, a mangueira de luz acende e apaga em ritmo gradual, realizando, diante da câmera, a figuração dilatada de uma trucagem: o movimento de fade in e out. Assim, encerra a apresentação e, devido à edição em loop, reúne-se, num corte seco que realiza o raccord $^{30}$, ao primeiro esquete, em que a mesma mangueira, captada no mesmo enquadramento, pisca num ritmo constante e acelerado, funcionando como vinheta do conjunto.

\footnotetext{
${ }^{28}$ Os esquetes, como as propagandas de televisão, não possuem títulos. Os "apelidos" que transcrevo aqui servem apenas à sua identificação no curso do texto. A descrição de cada um deles será feita adiante.

${ }^{29}$ Não se trata aqui da tecnologia efetivamente utilizada, o vídeo. Nesse caso, a referência ao aparato se realiza na remissão à história das produções audiovisuais.

30 “Tipo de montagem na qual as seqüências dos planos são, tanto quanto possível, apagadas como tais, de maneira que o espectador possa concentrar toda a sua atenção na continuidade da narrativa visual." [AUMONT, J.; MARIE, M. Dicionário teórico e crítico de cinema. São Paulo: Papirus, 2006, p. 251]. A prática do raccord foi aperfeiçoada no cinema de Hollywood da época clássica.
} 
Pode-se apontar, também, a temporalidade particular que se instaura nos vídeos. O esquete apelidado de "jabuti", posicionado logo após o esquete-vinheta de abertura do conjunto, impõe uma evidente desaceleração. Em primeiro lugar, devido às características associadas ao próprio bicho: incomunicabilidade, lentidão, vida longuíssima; é como se vivesse, realmente, em outro tempo. Em segundo lugar, devido à ação apresentada na cena: após alguns segundos de um aparente congelamento da imagem, a lente se afasta e o enquadramento se abre à medida que o jabuti se desloca, de modo que a porção visível do campo se amplia na velocidade do seu passo. O fim da cena é dado pelo limite de retração do zoom da câmera, que se mantém fixa e já não pode acompanhar o jabuti quando ele se desloca para fora do quadro.

As cenas seguintes estão impregnadas dessa experiência, como se dela derivasse um padrão temporal do qual a câmera não pudesse mais se livrar. Padrão que, inicialmente orgânico, tornou-se mecânico, e agora aparece nos movimentos de máquinas (ventilador, base giratória) e na velocidade de sucessão dos quadros no "aquário". O estabelecimento de uma temporalidade própria não se dá, portanto, pela dilatação ou resumo da experiência da duração através da manipulação da relação entre o tempo fílmico e o tempo diegético ${ }^{31}$, por saltos cronológicos no interior da "história", mas sim por uma quebra da solidariedade entre o tempo crônico e o tempo perceptivo numa experiência em que filme e "história" se equivalem. Nessa temporalidade particular se mantém, entretanto, uma perspectiva mensurável. Os momentos de fato se sucedem, os movimentos não ocultam sua velocidade, cenas particulares têm início, meio e fim ${ }^{32}$.

\footnotetext{
${ }^{31}$ Entre o tempo do filme e o tempo dos acontecimentos contados, segundo a terminologia de Étienne Souriaud. [Apud AUMONT, J.; MARIE, M. Op. cit.].

${ }^{32}$ Nesse sentido a temporalidade destes vídeos opõe-se àquilo que, segundo Eugênio Bucci, definiria o tempo da TV: "Observem que, vendo TV, temos a sensação de que tudo ali é um gerúndio interminável e, outra vez, totalizante, ainda que dissimulando essa sua condição. Os eventos se sucedem não propriamente numa sucessão, mas num acontecendo, num se sucedendo, na permanência de um, repito, gerúndio que não tem começo nem fim.[...] o passado e o futuro deságuam um no outro; não há começos encadeados a meios e fins; as narrativas lógicas se dissolvem numa pasta que, não obstante, tem um sentido profundo: o sentido de integrar pelo olhar.” [BUCCI, Eugênio. A crítica de televisão. In: BUCCI, Eugênio; KEHL, Maria Rita. Videologias: ensaios sobre televisão. São Paulo: Boitempo, 2004, p. 35-37]. Nos discursos mais entusiastas das "novas possibilidades" da imagem eletrônica, por sua vez, defende-se um hibridismo, um caráter fragmentário como especificidade do meio, especificidade que as manifestações mais "experimentais"
} 
Acredito que a estruturação do conjunto conservou da referência primeira à propaganda de televisão a característica de uma sucessão de esquetes autônomos, aparentados pelas três regras que enumerei na página 24 , ao discutir a eleição do objeto: contorno (são vídeos; serão submetidos à mesma regra de circulação), recorrências formais (aqui referentes a algumas soluções de formalização sedimentadas no conjunto de meu trabalho, e outras que surgiram da relação com o meio) e finalidade (dar a ver sua metodologia, revelar-se, tornar evidentes suas estratégias). No mais, cada um desses esquetes ${ }^{33}$ procura se impor numa imagem que resista à sucessão, encenando uma espécie de concorrência. A edição em loop do conjunto remete à repetição das mesmas propagandas nos diferentes intervalos.

Ainda assim, o conjunto foi intitulado de "Programa"34.

explorariam. Tampouco com esse suposto "tempo fragmentado" do vídeo digital se pode relacionar a temporalidade deste trabalho.

${ }^{33}$ Utilizo o termo "esquete" devido à menção a uma narrativa completa no sentido clássico (com começo, meio e fim) e à condição de peça ao mesmo tempo autônoma e combinável a outras. Cada uma das unidades do "Programa" encerra um acontecimento, constituindo algo como um "segmento figurativo" inteiro (cf. a citação de Eisenstein na p. 53.).

${ }^{34}$ Para além do programa de televisão - ele mesmo o intervalo entre os intervalos -, a palavra "programa" tem outras acepções interessantes para este trabalho. Por um lado, refere-se à composição de partes (de um espetáculo) e à discriminação de tópicos (de um curso, por exemplo); por outro, a uma exposição escrita de intenções (de uma chapa, de um partido, de um candidato), a algo que se pretende realizar, um projeto, um plano. [Cf. HOUAISS; VILLAR. Dicionário Houaiss da língua portuguesa. Rio de Janeiro: Objetiva, 2001]. 


\subsubsection{Primeiro esquete: "pisca-pisca"}

O primeiro esquete se inicia com um plano fixo no qual se vê uma mangueira de luz $z^{35}$ amarela disposta de modo a formar um retângulo sobre uma superfície plana branca. Dada a resistência do material, o retângulo obtido não é simétrico; seus cantos são arredondados e as arestas irregulares. O enquadramento é fechado na mangueira, que ocupa precisamente as extremidades da imagem. O tamanho real do retângulo filmado coincide com as dimensões internas de um televisor de 29 polegadas. Assim, quando o vídeo é exibido segundo as regras determinadas, a escala da imagem torna-se 1:1, o que possibilita que se estabeleça uma relação direta entre a mangueira, com sua função de realçamento, e o aparelho de televisão. A mangueira realiza uma espécie de mediação entre a imagem e o espaço concreto de transmissão. Mas ali não há qualquer outra imagem, e essa função apenas se efetiva numa permanência virtual da mangueira nos esquetes seguintes.

A duração do esquete, contido em um único plano fixo, é de 5 segundos. Nesse tempo, as lâmpadas da mangueira, ligada à rede elétrica num ponto além do quadro, se acendem e apagam alternadamente, em alta velocidade, produzindo a impressão de um movimento em sentido horário. Um ruído constante, produzido por um reator de lâmpada fluorescente, acompanha a imagem.

O primeiro esquete funciona, conforme já foi dito, como vinheta do conjunto. Não encerra exatamente uma narrativa, mas exibe padrões visuais que devem ser identificados com esse conjunto, delimitando a sua vigência, à maneira dos planos fixos de curtíssima metragem que se inserem na abertura e encerramento de um programa de televisão, ou entre seus intervalos comerciais. No caso do conjunto de vídeos aqui apresentado, pode ser que a presença da vinheta remeta a um programa ausente, algo que se consumaria entre cada uma das transmissões, o que, logo, levaria à inversão do estatuto do intervalo. O conjunto-intervalo revela, finalmente, ser o próprio "Programa". Mas essa suposta inversão possui um referente

\footnotetext{
${ }^{35}$ A mangueira de luz é um artefato industrial que consiste em uma seqüência de pequenas lâmpadas eqüidistantes envolta por uma única capa emborrachada transparente. Existente em diversas cores e vendida por metro, destina-se usualmente à decoração de fachadas e vitrines de estabelecimentos comerciais. Deve ser ligada a uma tomada. Para controlar a intensidade e a ordem de acendimento das lâmpadas, conseguindo diferentes efeitos de "movimento", usa-se um aparelho conhecido como seqüenciador.
} 
real, que o título do trabalho explora. Afinal, cada vez menos se hierarquizam conteúdos no gerúndio da transmissão televisiva; o que se vê é justamente uma equivalência entre intervalo e programa. A vinheta, assim, é, já no seu uso cotidiano, um recurso de diferenciação entre iguais.

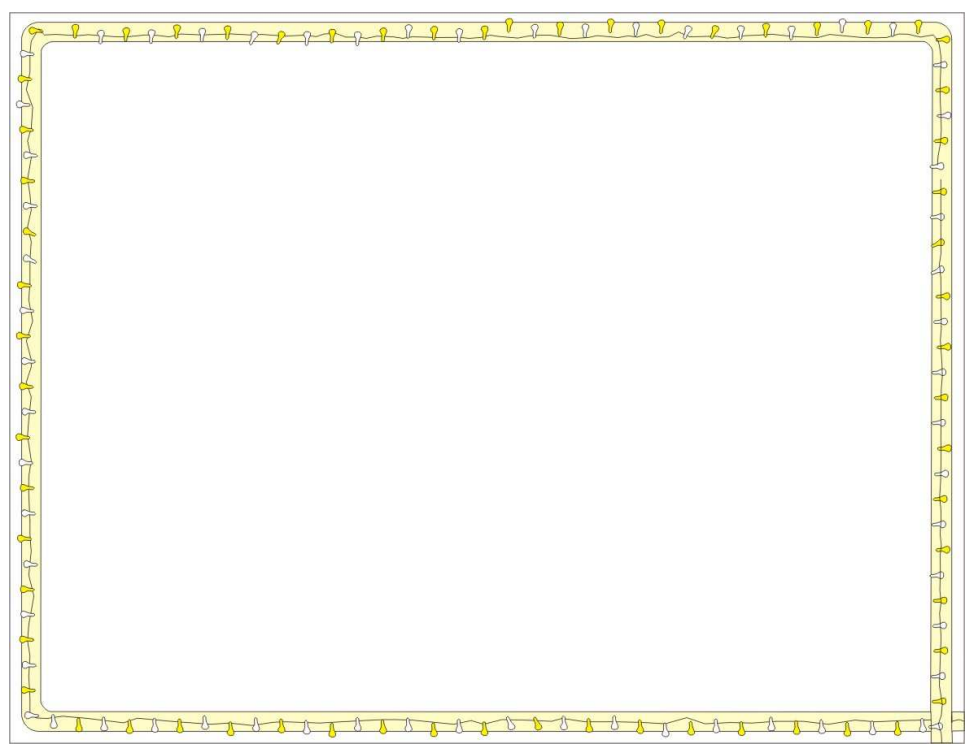

Representação gráfica do plano 


\subsubsection{Segundo esquete: "jabuti"}

Vê-se, de cima, um jabuti adulto posicionado sobre uma superfície branca ${ }^{36}$. O enquadramento é bastante fechado no jabuti. Ele tem cabeça, rabo e patas contraídos para dentro do casco e, portanto, invisíveis. Após um período de imobilidade, aos poucos começa a se movimentar; expõe as patas e a cabeça e desloca-se. O plano mantém-se fixo.
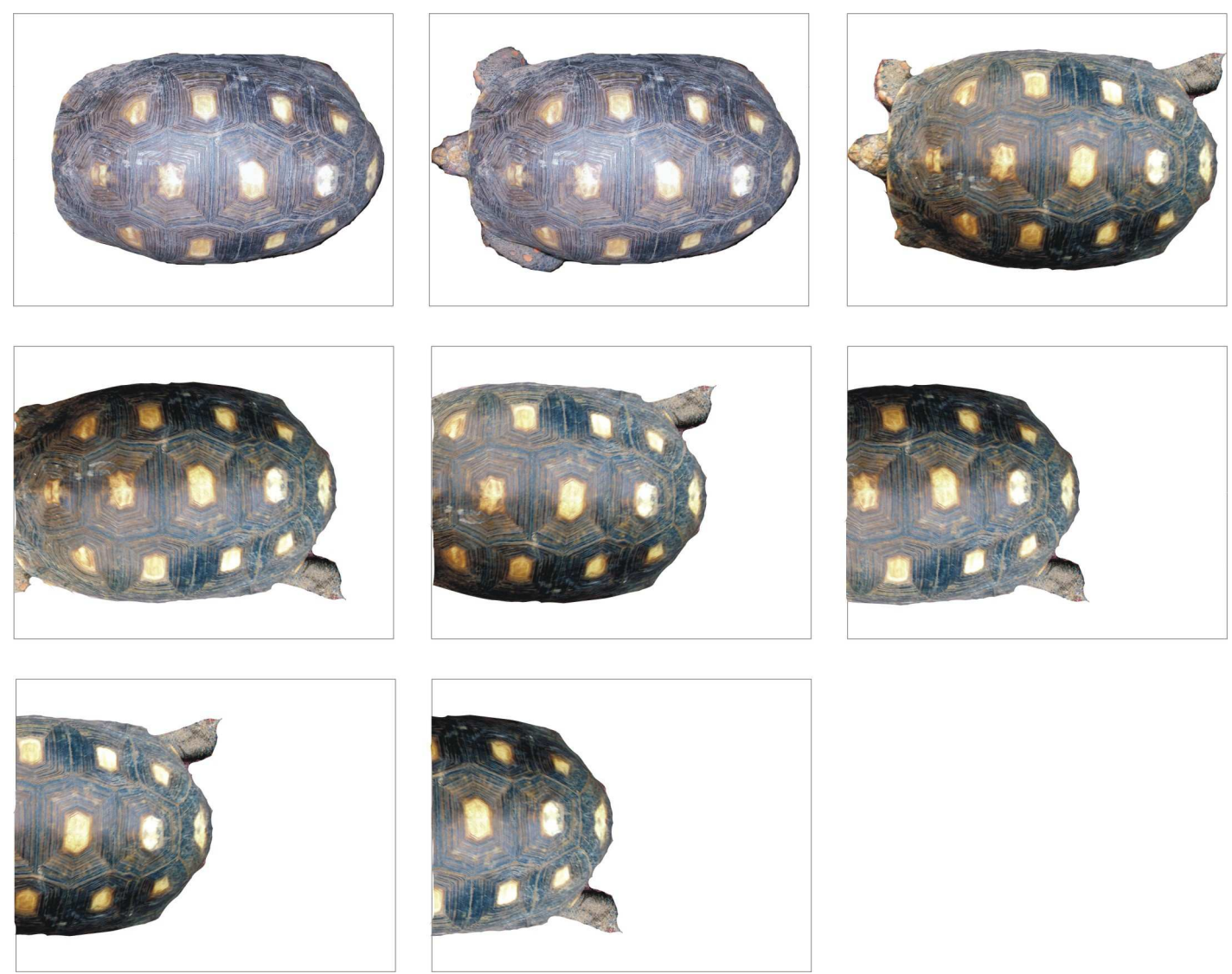

Storyboard do esquete - primeira parte

\footnotetext{
${ }^{36} \mathrm{Na}$ escolha da superfície, apresentava-se a opção de citar o próprio habitat do animal, usando um terreno de terra batida. Essa opção foi abandonada porque não se pretendia, nessa seqüência, reforçar outra figura de natureza que não o próprio jabuti. A qualidade orgânica do jabuti e a qualidade mecânica da câmera deveriam se relacionar com um número mínimo de intermediários perceptíveis.
} 
Quando ele atinge uma posição em que apenas a metade posterior do seu corpo é visível, o plano passa a alterar-se, ainda que a câmera não se mova. Retrai-se mecanicamente o zoom à medida que o jabuti se desloca, de modo a conseguir manter sempre metade de seu corpo dentro do quadro. O efeito é uma diminuição progressiva do tamanho da imagem do objeto filmado (afastamento), ditada por seu próprio ritmo de movimentação. As duas dimensões, largura e profundidade, vinculam-se provisoriamente, estabelecendo uma regra de proporção baseada numa afinidade mimética entre o aparato e o objeto. O vínculo é interrompido quando a capacidade (negativa) de aproximação do zoom se esgota e o plano torna-se novamente fixo. O jabuti continua a se deslocar e deixa o quadro. Não há captação de som direto ou adição de trilha sonora; o esquete é silencioso.
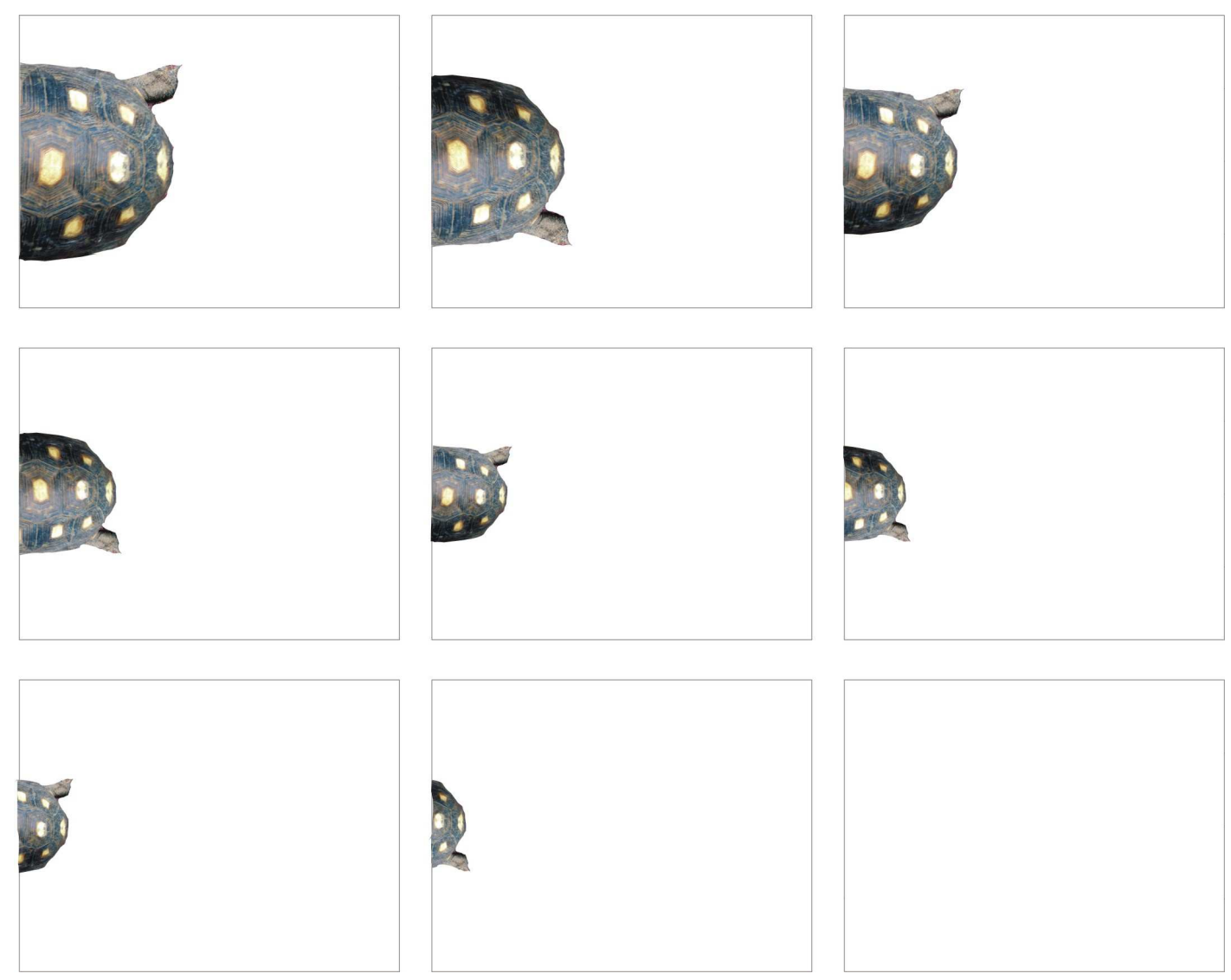

Storyboard do esquete - segunda parte 
A câmera é posicionada numa distância determinada do objeto, em que a aproximação máxima possibilitada pelo zoom coincide com um enquadramento totalmente fechado em seus contornos no plano inicial; dessa distância advém o enquadramento final. É interessante notar que a manipulação do zoom, sendo mecânica, está sempre "atrasada" em relação ao deslocamento do jabuti, que afirma uma primazia na relação mimética ${ }^{37}$. Nesse sentido, não se sabe qual será a duração exata da cena, que depende da velocidade de deslocamento do jabuti.

O jabuti representa muito parcamente a idéia de liberdade que se costuma associar à vida animal - há a "prisão" no casco, a lentidão, a indiferença afetiva, a adaptabilidade ao cativeiro doméstico; o jabuti é um animal cuja aparência de "solidez" e "durabilidade" remete quase a uma existência mineral ${ }^{38}$. $\mathrm{O}$ fato de o deslocamento do jabuti ocorrer num ritmo inconstante e transcender a relação mimética e os limites do quadro estabelece uma impossibilidade para o próprio espectador, dada pelo limite físico do movimento da máquina (limite físico que, por sua vez, não é da ordem do desenvolvimento tecnológico geral, mas dos atributos daquela câmera particular em relação a um conjunto estabelecido de regras). Embora o zoom, dentre os recursos de movimento de câmera, seja aquele que menos se pode associar ao olho humano ${ }^{39}$, é com a máquina que o espectador pode se identificar, e não com o jabuti o que faz com que, paralelamente, o conhecimento possível não seja o do objeto visto, mas do instrumento de mediação do olhar. A primazia do jabuti logo se mostra indiferença (e a indiferença não seria, justamente, a qualidade do inorgânico?).

\footnotetext{
${ }^{37}$ Havia a possibilidade de filmar o deslocamento do jabuti sem o recurso do zoom óptico, com um plano fixo no enquadramento final, e, na pós-produção, realizar digitalmente a aproximação. Nesse caso, poderia se conseguir a coincidência exata dos movimentos, minimizando a existência de um operador da câmera, $o$ que parece positivo. Entretanto, talvez nesse "atraso" do movimento mecânico resida o índice de que há uma construção artificial de afinidade.

${ }^{38}$ E nesse sentido é importante o primeiro plano da sequiência, em que se vê apenas o casco.

39 "Observemos [...] as interpretações dadas com freqüência aos movimentos de câmera: a panorâmica seria o equivalente do olho que gira na órbita, o travelling, de um deslocamento do olhar; quanto ao zoom, dificilmente interpretável em termos de simples posição do suposto sujeito do olhar, às vezes tentou-se lê-lo como 'focalização' da atenção de um personagem.” [AUMONT, J. et al. A estética do filme. Campinas: Papirus, 1995, p. 43].
} 


\subsubsection{Terceiro esquete: "maquete"}

A câmera mantém-se fixa. Um objeto posicionado à sua frente gira sobre uma base circular motorizada, revelando diferentes faces. Trata-se de uma maquete dividida em quatro espaços de largura e profundidade idênticas, separados por vãos uniformes, onde se representam quatro ambientes domésticos: copa-cozinha, sala, banheiro e quarto. No primeiro quadro vê-se uma superfície branca que, gradualmente, de acordo com o movimento da base, dá lugar ao primeiro ambiente. À medida que esse ambiente entra em quadro, ouvem-se sons a ele relacionados. Todos os objetos presentes têm desenhos simplificados e são pintados de branco; não há detalhamento nas imagens ${ }^{40}$. Quando metade do ambiente sai de quadro os sons são interrompidos. O enquadramento é suficientemente fechado para que não se perceba de imediato toda a maquete; os seus limites nunca são visíveis, tampouco a base giratória ou o motor. Entra em quadro o segundo ambiente: ouvem-se seus ruídos, interrompidos de súbito quando metade dele deixa o quadro. E assim sucessivamente.

Como se disse, os quatro espaços têm largura e profundidade idênticas. Em conseqüência, o que varia, produzindo a diferença de tamanho dos ambientes projetados, são a escala dos objetos que os caracterizam e os pés-direitos. Assim, o espectador experimenta diferentes estados de aproximação nos diversos ambientes, embora a maquete esteja sempre no mesmo local - movendo-se sobre um eixo central -, a câmera se mantenha sempre fixa, a distância focal seja constante e não se faça uso de recursos ópticos ou eletrônicos de aproximação.

\footnotetext{
${ }^{40}$ Embora os objetos da maquete sejam simplificados, sua aparência é bastante semelhante à dos objetos reais que representam. Evita-se o recurso a materiais "pobres" ou acabamentos toscos. De fato, pretende-se que exista alguma ambigüidade na imagem, que se resolva à medida que, com o movimento circular, a compleição física da própria maquete possa ser apreendida.
} 


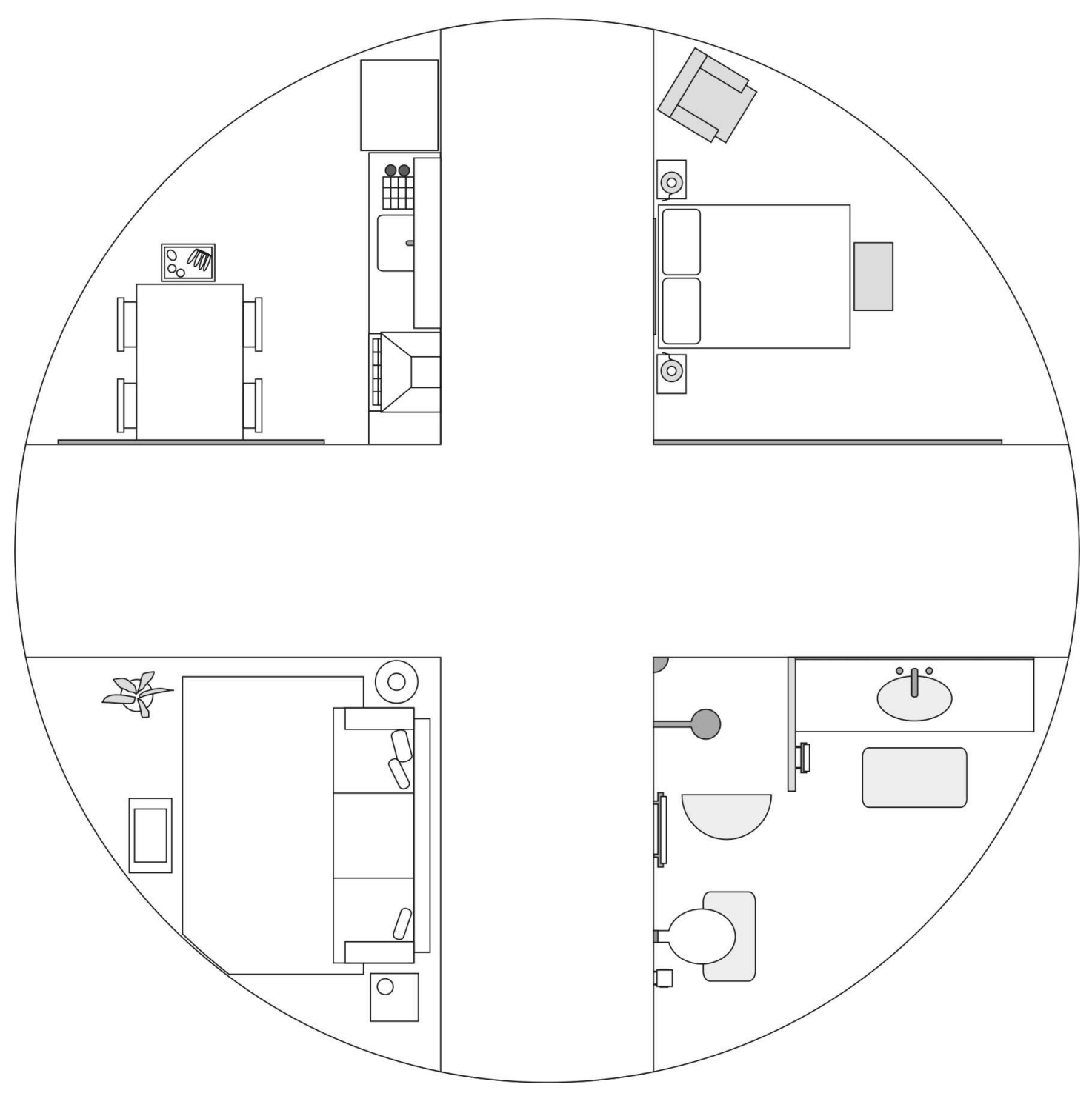

Planta-baixa da maquete, mostrando os quatro ambientes e os vãos que os separam 

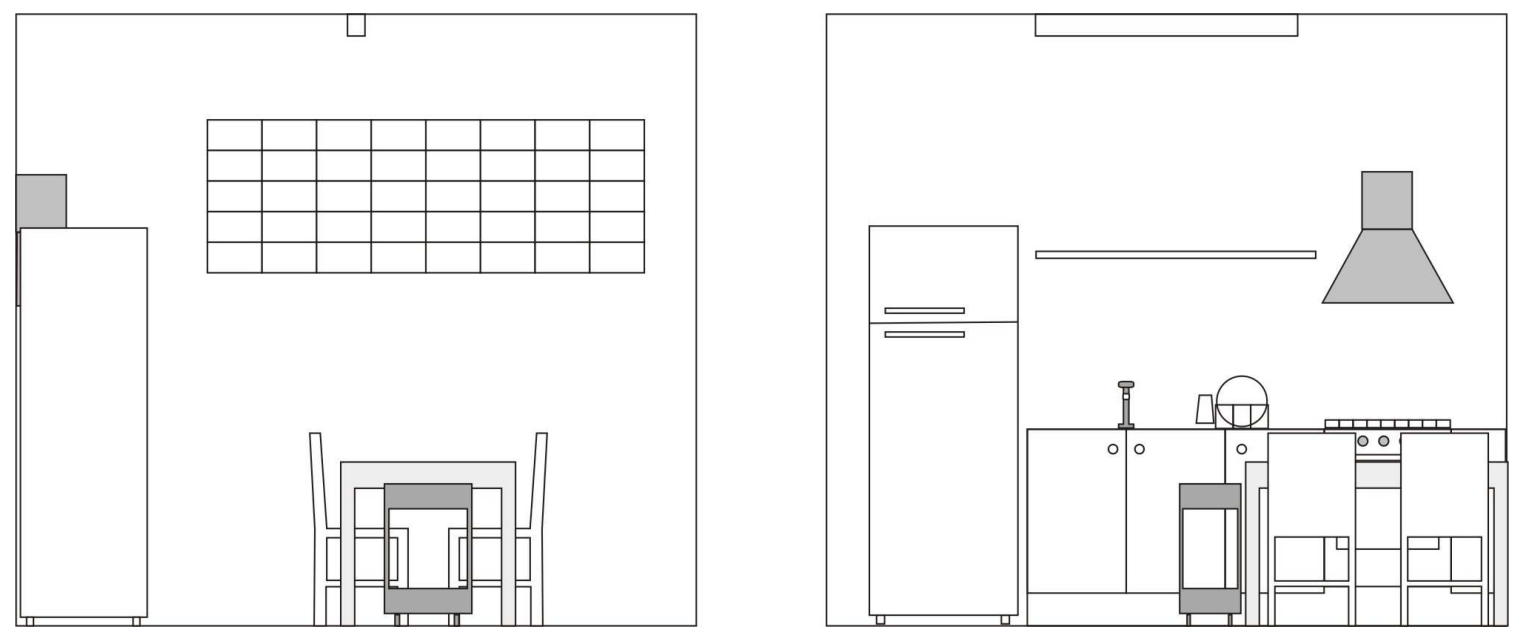

Elevações da copa-cozinha
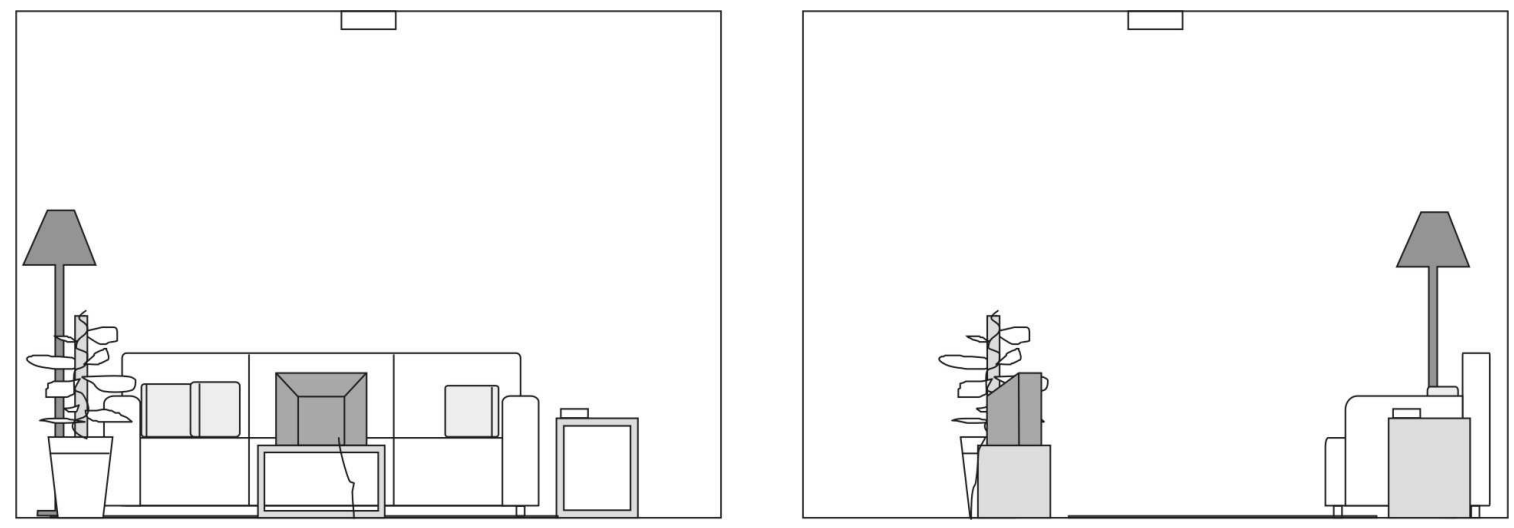

Elevações da sala
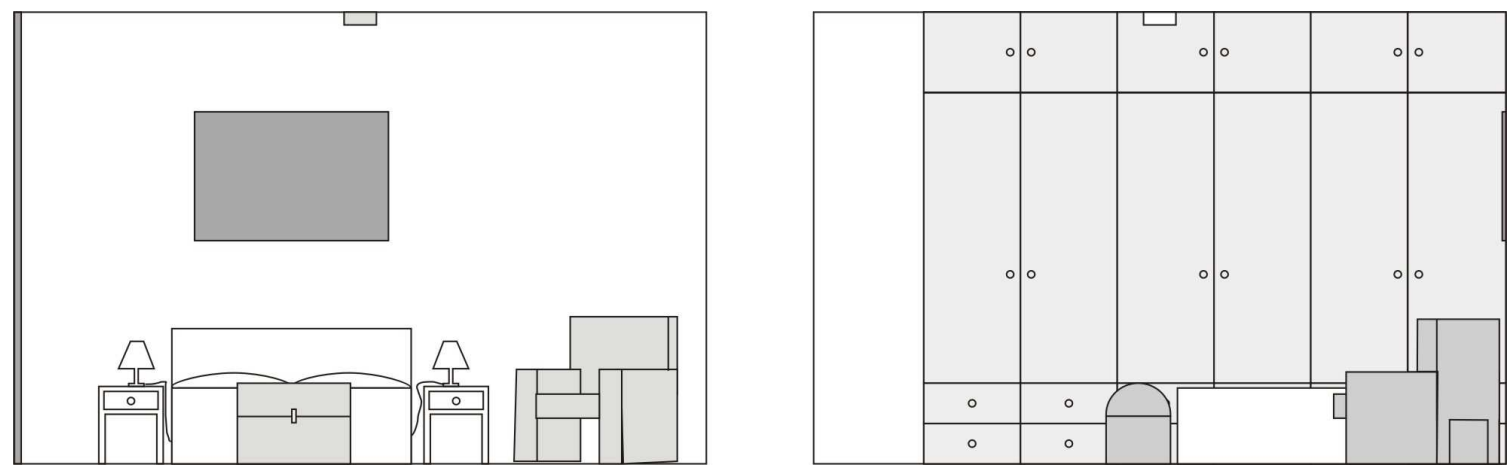

Elevações do quarto 

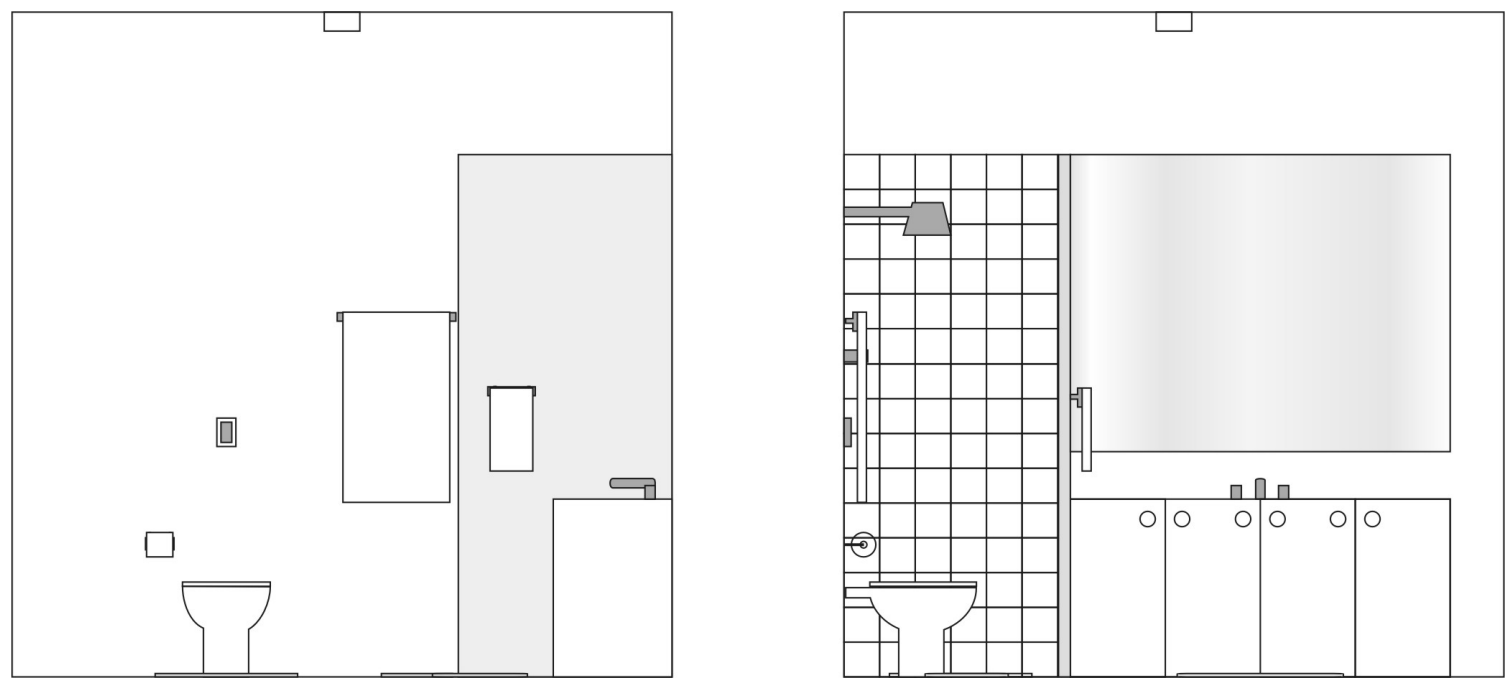

Elevações do banheiro

A maquete realiza cinco movimentos circulares completos (voltas) diante da câmera. A cada volta, embora as imagens se repitam, inalteradas, os sons sofrem modificações. Inicia-se a cena com uma massa sonora composta pela emissão simultânea de cinco ruídos autônomos ${ }^{41}$ para cada um dos ambientes. Assim, na copa-cozinha, por exemplo, combinam-se o ruído de um líquido sendo despejado num copo, o ruído de um exaustor ligado, o ruído de talheres e louças sendo manipulados, o ruído de uma faca cortando vegetais sobre uma tábua de madeira e o ruído de água fervendo. À medida que a maquete gira e o ambiente volta a aparecer, um desses ruídos é subtraído da massa. Na segunda volta, então, os sons da copa-cozinha são os do exaustor, dos talheres e louças, dos vegetais sendo cortados e da água fervendo. Assim sucedem-se as voltas, até que, na última, resta apenas um ruído. Subtrai-se o ruído mais marcante da massa a cada volta, de modo que o ruído remanescente, ao final das cinco voltas, é sempre o mais discreto (no caso da copa-cozinha, resta o som de fervura).

\footnotetext{
${ }^{41}$ Usam-se, sobretudo, ruídos de sala. Os ruídos de sala, ou foley sounds, são sons-ambiente incidentais produzidos em decorrência de ações que se desenrolam na cena (por exemplo, sons de passos, sons de portas batendo etc.). No cinema narrativo, mesmo em cenas em que se dá a captação de som direto costumase recriar artificialmente alguns ruídos de sala na pós-produção, o que permite maior controle das intensidades no momento de mixagem. Aqui, a grande maioria dos ruídos é retirada de arquivos preexistentes, o que lhes confere uma qualidade limpa, "seca", devida à quase inexistência de reverberação.
} 
A seleção dos ruídos que compõem as massas não obedece a critérios de verossimilhança; apesar da presença simultânea, os ruídos sugerem ações que, em geral, não poderiam coincidir temporalmente dentro de uma narrativa clássica. Não se constroem personagens completos, cujas ações (invisíveis) seriam sonorizadas. Tampouco se pretende articular as massas sonoras dos diferentes ambientes, indicando uma teleologia nas ações sucessivas. As funções convencionais do som fílmico ${ }^{42}$ - chamar a atenção para determinados pontos na imagem, ou seja, orientar a visão e a leitura; permitir continuidade linear a imagens fragmentárias; reforçar o conteúdo dramático, multiplicando informações; situar a imagem no tempo e no espaço - não se realizam completamente, uma vez que (1) a maioria dos objetos sonorizados sequer está presente na imagem; (2) os sons têm evidente padrão fragmentário (padrão que dificulta, inclusive, a percepção de que se trata de um único objeto em todas as imagens, apreendido em posições diferentes); (3) a situação espaciotemporal dada pelo som não corresponde à "realidade" captada (a imagem retrata, como sabemos, uma maquete). Conserva-se, apenas, a função de multiplicação de informações, mas descolada de qualquer aplicação dramática.

Apesar disso, o espectador, acostumado ao padrão, se mantém constantemente incitado a tentar encerrar conexões narrativas. $\mathrm{O}$ fato de que se trata de uma sucessão de subtrações torna-se claro apenas no final do esquete.

\footnotetext{
${ }^{42}$ Refiro-me aos padrões de relação entre som e imagem que se criaram e consolidaram nas grandes produções de Hollywood desde a década de 1930. Considera-se que tais padrões adquiriram o estatuto de convenções em fins da década de 1970, em filmes como Guerra nas Estrelas - Episódio VI: Uma Nova Esperança (1977, dirigido por George Lucas) e Indiana Jones e os Caçadores da Arca Perdida (1981, dirigido por Steven Spielberg).
} 


\begin{tabular}{|c|c|c|c|c|c|}
\hline & $1^{\mathrm{a}}$ volta & $2^{\mathrm{a}}$ volta & $3^{\mathrm{a}}$ volta & $4^{\mathrm{a}}$ volta & $5^{a}$ volta \\
\hline copa-cozinha & $\begin{array}{l}\text {-líquido } \\
\text { sendo } \\
\text { servido } \\
\text {-exaustor } \\
\text {-talheres/ } \\
\text { louças } \\
\text { - corte de } \\
\text { vegetais } \\
\text {-fervura }\end{array}$ & $\begin{array}{l}\text {-exaustor } \\
\text {-talheres/ } \\
\text { louças } \\
\text { - corte de } \\
\text { vegetais } \\
\text {-fervura }\end{array}$ & $\begin{array}{l}\text {-talheres/ } \\
\text { louças } \\
\text { - corte de } \\
\text { vegetais } \\
\text {-fervura }\end{array}$ & $\begin{array}{l}\text { - corte de } \\
\text { vegetais } \\
\text {-fervura }\end{array}$ & -fervura \\
\hline sala & $\begin{array}{l}\text {-televisor } \\
\text { (mudando os } \\
\text { canais) } \\
\text { - móveis } \\
\text { arrastados } \\
\text {-aspirador de } \\
\text { pó } \\
\text {-jornal } \\
\text { impresso } \\
\text {-som externo } \\
\text { (trânsito) }\end{array}$ & $\begin{array}{l}\text {-móveis } \\
\text { arrastados } \\
\text {-aspirador de } \\
\text { pó } \\
\text {-jornal } \\
\text { impresso } \\
\text {-som externo } \\
\text { (trânsito) }\end{array}$ & $\begin{array}{l}\text {-aspirador de } \\
\text { pó } \\
\text {-jornal } \\
\text { impresso } \\
\text {-som externo } \\
\text { (trânsito) }\end{array}$ & $\begin{array}{l}\text {-jornal } \\
\text { impresso } \\
\text {-som externo } \\
\text { (trânsito) }\end{array}$ & $\begin{array}{l}\text {-som } \\
\text { externo } \\
\text { (trânsito) }\end{array}$ \\
\hline banheiro & $\begin{array}{l}\text {-cortina de } \\
\text { "box" } \\
\text {-chuveiro } \\
\text {-barbeador } \\
\text { elétrico } \\
\text { - água } \\
\text { passando por } \\
\text { cano } \\
\text {-caixa de } \\
\text { descarga } \\
\text { enchendo }\end{array}$ & $\begin{array}{l}\text {-chuveiro } \\
\text {-barbeador } \\
\text { elétrico } \\
\text { - água } \\
\text { passando por } \\
\text { cano } \\
\text {-caixa de } \\
\text { descarga } \\
\text { enchendo }\end{array}$ & $\begin{array}{l}\text {-barbeador } \\
\text { elétrico } \\
\text { - água } \\
\text { passando por } \\
\text { cano } \\
\text {-caixa de } \\
\text { descarga } \\
\text { enchendo }\end{array}$ & $\begin{array}{l}\text { - água } \\
\text { passando por } \\
\text { cano } \\
\text {-caixa de } \\
\text { descarga } \\
\text { enchendo }\end{array}$ & $\begin{array}{l}\text {-caixa de } \\
\text { descarga } \\
\text { enchendo }\end{array}$ \\
\hline quarto & $\begin{array}{l}\text {-despertador } \\
\text {-zíper } \\
\text {-roupas de } \\
\text { cama } \\
\text { manipuladas } \\
\text { - ventilador } \\
\text { de teto } \\
\text {-tic-tac }\end{array}$ & $\begin{array}{l}\text {-zíper } \\
\text {-roupas de } \\
\text { cama } \\
\text { manipuladas } \\
\text { - ventilador } \\
\text { de teto } \\
\text {-tic-tac }\end{array}$ & $\begin{array}{l}\text {-roupas de } \\
\text { cama } \\
\text { manipuladas } \\
\text { - ventilador } \\
\text { de teto } \\
\text {-tic-tac }\end{array}$ & $\begin{array}{l}\text { - ventilador } \\
\text { de teto } \\
\text {-tic-tac }\end{array}$ & -tic-tac \\
\hline
\end{tabular}

Ruídos utilizados no esquete, organizados em função dos ambientes e do número de voltas 


\subsubsection{Quarto esquete: "aquário"}

Dezesseis pessoas distribuem-se em quatro filas de uma arquibancada. Filmadas em plano fixo, as pessoas seguram, cada uma, uma placa contendo o fragmento de uma imagem que se completa no conjunto das dezesseis placas. A imagem é apropriada de um acessório, vendido em lojas especializadas, destinado à decoração de aquários: uma folha impressa e plastificada, encontrada em várias dimensões, representando ambientes subaquáticos, com algas, plantas, corais e, muitas vezes, mesmo peixes e crustáceos. Essa folha deve ser posicionada junto à parede posterior do aquário, produzindo a ilusão de que se trata de um espaço mais amplo e diversificado do que de fato é. A imagem possui uma tipologia claramente identificável: cores fortes, colagens evidentes, escala agigantada; sua artificialidade é ostensiva ${ }^{43}$.

O mesmo fragmento da imagem se repete nas duas faces de cada placa, com uma diferença: em uma das faces vê-se, sobre a imagem apropriada da folha decorativa, um peixe amarelo em primeiro plano. A cena se inicia com todas as placas posicionadas frontalmente à câmera, exibindo a mesma face, sem o peixe. Ouvem-se ruídos aquáticos. Seguindo um ritmo constante e uma seqüência sincrônica predeterminada, as pessoas passam a girar suas placas, exibindo e ocultando o peixe de modo a simular a passagem de um cardume pela "tela" formada pela junção das placas. Quando o primeiro peixe aparece, sobrepõe-se aos ruídos uma música executada por três vibrafones que emitem sons de timbres e freqüências diferentes. A câmera permanece fixa durante toda a cena, que se encerra com a formação inicial.

A trilha musical foi composta por um músico que trabalha com cinema e propaganda, de modo que se reproduziu o procedimento corrente: foram comunicadas, da maneira mais clara possível, as "qualidades" que se esperava da composição, dando-se orientações relacionadas aos "efeitos" pretendidos. Optou-se, aqui, pela trilha musical como citação explícita a um recurso corrente dos produtos audiovisuais - e particularmente das propagandas televisivas.

\footnotetext{
${ }^{43}$ Muitas vezes o ambiente representado contradiz o ambiente real do interior do aquário (peixes de água doce, por exemplo, convivem com imagens de formações de coral e conchas).
} 
A respeito desse esquete deve-se considerar, em primeiro lugar, que ocorre uma multiplicação de planos (autocontidos), que simulam, cada qual, uma profundidade de campo. Assim, o plano formado pela junção das placas na posição inicial simula um ambiente aquático natural. No entanto, à medida que o peixe aparece, ganhando o primeiro plano, esse plano anterior é achatado, voltando à sua condição de uso: folha impressa com fim decorativo. O fato da escala do peixe não coincidir com a da imagem de fundo reforça esse descolamento. O novo ambiente simulado é, então, o interior de um aquário decorado. Este, entretanto, também assume a condição plana, desta vez de imagem sobreposta a um conjunto de placas rígidas postas em movimento por atores. O terceiro plano é o da imagem filmada, também ele simulando sua profundidade de campo - contraditada, por sua vez, pela tela do televisor. Passam-se duas ações ligadas por uma lei causal, mas irreconciliáveis numa mesma dimensão narrativa verossímil: um cardume atravessa o plano do aquário; atores realizam uma coreografia com placas no plano filmado. Também o som se organiza em planos distintos; os ruídos aquáticos se associam à imagem da folha decorativa, enquanto a música se associa à passagem dos peixes. Ruídos e música são claramente distinguíveis, e impõem dois graus de verossimilhança.

A analogia entre o aquário e o televisor é antiga. Ambos são caixas; suas proporções são semelhantes; ambos se dão a ver frontalmente; em ambos se assiste a realidades indiferentes à presença do espectador; ambos carregam ilusões relacionadas à profundidade. No caso do aquário, quando visto de frente, a deformação produzida pelo vidro e pela água dificulta que se determine a profundidade do espaço e dos objetos, que se achatam. No caso do televisor, uma cena real (de um espaço tridimensional) captada em outro lugar é transmitida como imagem bidimensional pela tela. Mas subsiste a figura imaginária de que a cena transmitida se desenrolaria no interior do aparelho ${ }^{44}$. Nesses (e em alguns outros) sentidos a analogia foi bastante explorada ${ }^{45}$. Aqui, ela é tomada como dado já culturalizado e condizente

\footnotetext{
${ }^{44}$ Em A fantástica fábrica de chocolates, de Roald Dahl [São Paulo: Martins Fontes, 2004], cria-se um dispositivo de "tele-transporte" através do qual se entra no interior de uma televisão. Nos filmes de terror, é bastante convencional a passagem de elementos da imagem televisiva à realidade.

${ }^{45}$ Há um trabalho do artista coreano Nam June Paik (Video Fish, 1975), por exemplo, em que se posicionam aquários com plantas e peixes vivos diante de monitores de televisão que transmitem diferentes imagens. Em Real Fish/Live Fish (1982), Paik coloca um tanque com peixes reais dentro de uma caixa
} 
com uma determinada posição ideológica em relação à imagem videográfica. A mediação das placas reitera, no jogo de planos, a intencionalidade no uso dos recursos e a artificialidade de toda a construção, remetendo justamente para aquilo que, na produção do vídeo, há de fixo e esquadrinhado.

A analogia entre o televisor e o aquário, mas também o uso da trilha musical, a simulação de um movimento pela sucessão evidente de quadros estáticos, a produção de uma única imagem por fragmentos reunidos, a participação de um grupo grande de pessoas empenhado na veiculação de uma mesma mensagem ${ }^{46}$ são estratégias que foram apropriadas de referentes externos e são despidas de qualquer pretensão de autenticidade.

esvaziada de um monitor de TV, que é filmado, sendo as imagens transmitidas ao vivo por um monitor contíguo. Arlindo Machado, buscando enumerar as "especificidades do vídeo", diz: "Imagem ruidosa, que denuncia continuamente sua natureza fantasmática, a figura videográfica se caracteriza, antes de mais nada, pela sua extraordinária capacidade de metamorfose. [...] Não sem motivo, o analista de imagem eletrônica Ernie Tee aponta a água como a melhor metáfora para o vídeo, considerando que tanto um como o outro diluem a representação (já não se observou a estreita semelhança entre o aparelho receptor de TV e o aquário?)." [MACHADO, Arlindo. Op. cit., 1993, p. 49]. Nesse sentido, pode-se perceber que a analogia não é apenas fato dado, mas serve à afirmação de posições ideológicas, em que a suposta qualidade de "metamorfose" e "diluição" da imagem eletrônica dá-se sob o álibi da "inocência" dos peixes de aquário.

${ }^{46} \mathrm{Na}$ abertura das Olimpíadas de Moscou, realizadas em 1980, um grande painel formado por milhares de pessoas segurando placas avulsas mostrava a imagem do mascote, o urso Misha. Em determinado momento, o urso chorava e uma lágrima caía, descendo a arquibancada através das diferentes placas. Esses recursos passaram a ser usados, também, nas propagandas de televisão, reforçando a adesão de um suposto público às diferentes propostas institucionais. 

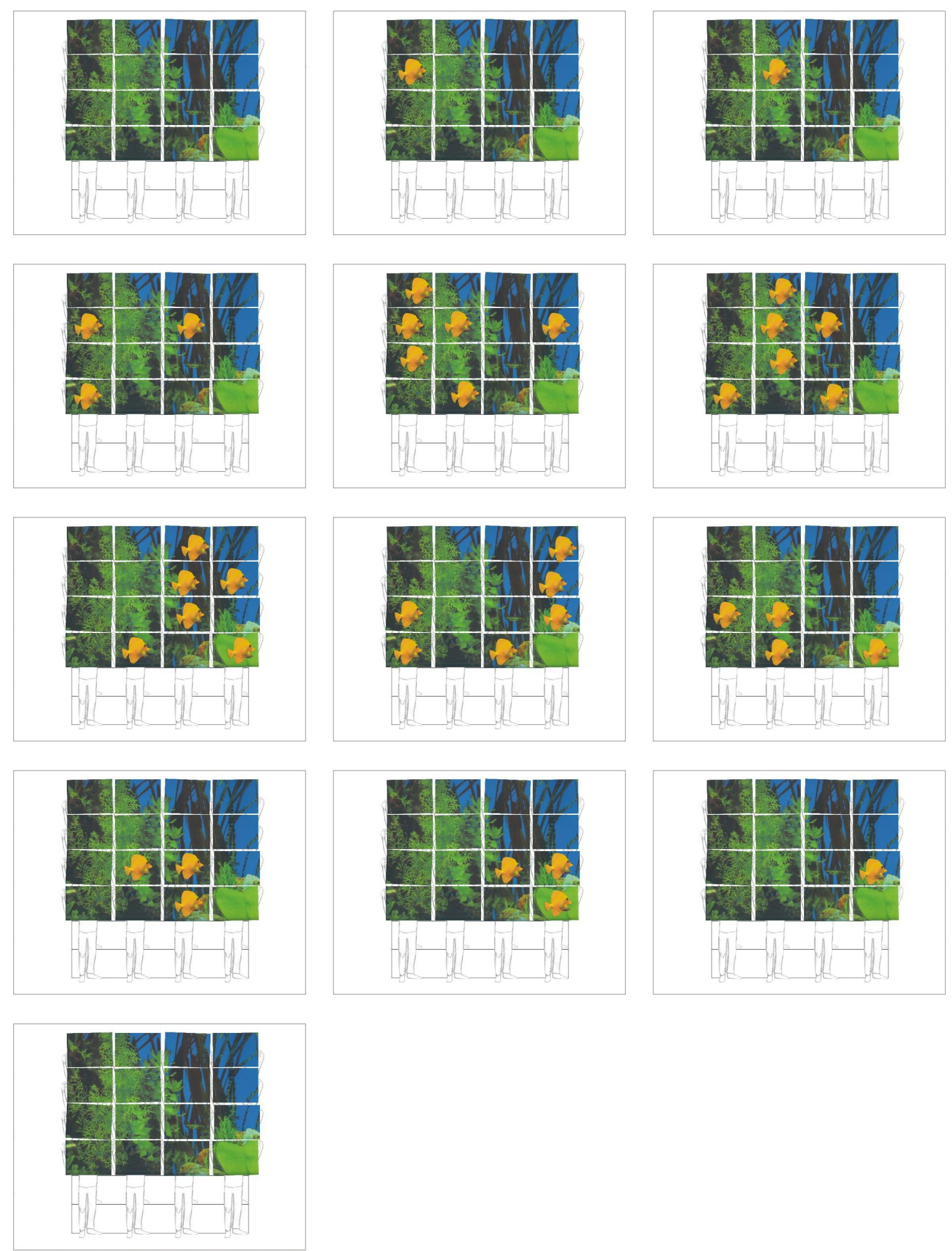

Storyboard do esquete 


\subsubsection{Quinto esquete: "ventilador"}

No centro vê-se, frontalmente, um ventilador desligado instalado na parede e, em primeiro plano, cinco varais com tiras de fita metálica prateada do mesmo comprimento, instaladas à mesma distância, que atravessam o quadro. $\mathrm{O}$ ventilador é ligado e passa a realizar dois movimentos simultâneos: as pás giram em sentido horário em torno de um eixo central perpendicular à parede, produzindo o vento, e o próprio aparelho oscila lateralmente, virandose para a direita e para a esquerda numa abertura de 120 graus em torno de um eixo paralelo à parede, distribuindo o vento pelo ambiente. As tiras de fita metálica balançam de acordo com sua posição no varal, produzindo um som específico, semelhante ao da chuva. Ocorre uma projeção da oscilação lateral do ventilador no plano virtual formado pelos varais, criando-se um movimento ilusório: o deslocamento horizontal do grupo de tiras em balanço. A câmera mantém-se fixa enquanto o ventilador realiza um primeiro ciclo completo de oscilação. Quando ele retorna à posição inicial, a câmera, presa a um tripé, passa também a mover-se: realiza um movimento panorâmico, reproduzindo a oscilação do ventilador. Assim, a câmera (e, conseqüentemente, o ponto de vista do espectador) move-se para a direita, retorna à posição frontal e move-se para a esquerda, sempre imitando a velocidade e as "imperfeições" do movimento do aparelho.

Os varais de tiras de fita metálica, disponíveis em diversas cores, costumam ser usados nos pátios e espaços externos de estabelecimentos comerciais. Balançando pela ação do vento, produzem um efeito óptico e sonoro que chama a atenção dos motoristas e transeuntes, que, no entanto, não devem se deter neles, mas atentar para o espaço circundante, remetendo-se à finalidade comercial do estabelecimento. Os varais, então, cumprem um papel limitado no processo de atração de público: restringem-se a uma primeira captação da atenção, devendo ser suficientemente "vazios" para permitir uma rápida passagem para o que realmente importa. Constituem, como já se apontou, recursos transitivos para "dar a ver", mediadores entre o estabelecimento e a atenção dos passantes, dada a profusão de "atrativos" presentes nas ruas. Cumprem, também, papel decorativo; emprestam aos estabelecimentos certa leveza, tornam-lhes informais, convidativos. 

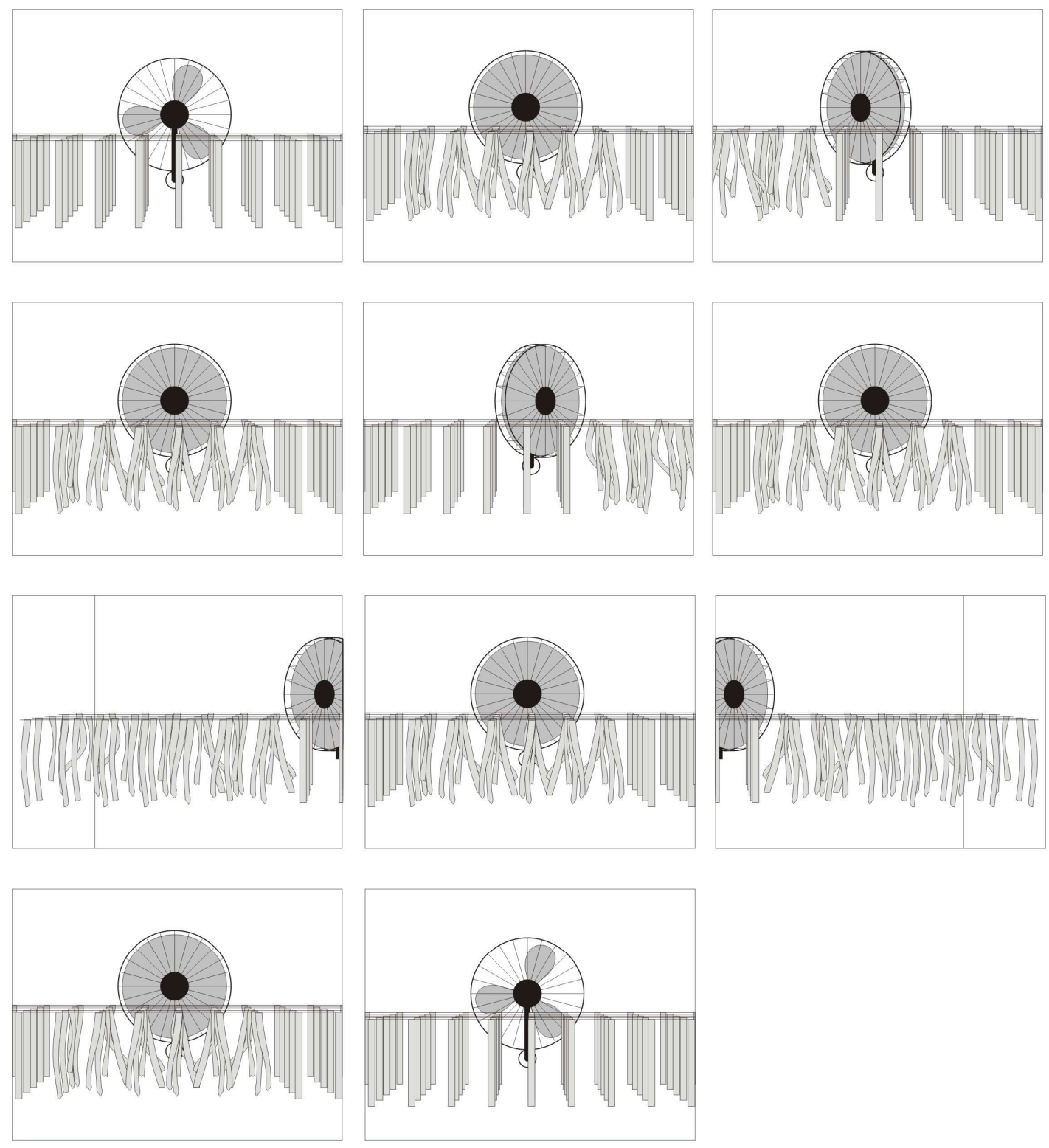

Storyboard do esquete 
Nesse esquete, os varais estão posicionados a meio caminho entre a câmera e o ventilador. Não participam diretamente do jogo mimético, mas recolhem as suas projeções na primeira oscilação do ventilador, direcionam o olhar do espectador dentro do plano fixo, conduzindo-o para uma extensão horizontal do campo que lhe escapa; na segunda oscilação, a câmera passa a mover-se, buscando exibir aquilo que, na primeira oscilação, recusava-se ao olhar. Trata-se, entretanto, da visibilidade dos movimentos predeterminados de um objeto "vazio", "sem conteúdo". O espaço circundante é neutro, vêem-se apenas paredes brancas, incapazes de indicar qualquer uso ou finalidade do espaço. O processo mostra-se autoreflexivo, uma vez que os varais devolvem incessantemente ao espectador sua própria disposição escópica. 


\subsubsection{Sexto esquete: "pisca-fade"}

Trata-se do esquete de encerramento do conjunto, e, portanto, ponto de efetivação do loop. O enquadramento é idêntico ao do "pisca-pisca". Vê-se a mesma mangueira de luz, na mesma posição. O plano mantém-se fixo durante toda a cena. Nos primeiros segundos, todas as lâmpadas da mangueira estão apagadas. Elas se acendem simultaneamente num ritmo gradual bastante lento, atingindo um nível máximo de luminosidade. A partir daí, passa a diminuir a intensidade de luz, até que as lâmpadas se apagam completamente. O ruído utilizado no "pisca-pisca", de um reator de lâmpada fluorescente, reaparece - agora variando de intensidade numa progressão constante, sincrônica à imagem.

Pode-se considerar que o esquete remete, como já foi dito, a uma trucagem: os efeitos de transição conhecidos como fade in e out. Trata-se de recursos utilizados no processo de montagem de um filme nos quais uma imagem aparece/ desaparece gradualmente a partir do preto total. O par fade out/ fade in, nessa ordem, é utilizado no cinema americano clássico para marcar a passagem entre seqüências distintas, indicando deslocamentos espaciotemporais. Aqui a ordem se inverte e a marcação se refere, antes, à transição entre o final e o início do conjunto de vídeos. Essa transição não se realiza como efeito de pós-produção, mas é citada numa ação que se efetiva no momento de captação. A transição propriamente dita, a mudança de plano entre esse esquete e o seguinte (o primeiro da seqüência), dá-se num corte seco, imperceptível, uma vez que se mantêm a câmera fixa, o mesmo enquadramento e o mesmo objeto filmado.

A função de vinheta que se atribuiu ao "pisca-pisca" aqui também se aplica. Esta seria uma vinheta de encerramento, guardando semelhanças formais com a vinheta de abertura do "Programa" mas se diferenciando dela por uma marcação evidente de término. 


\section{Pós-produção}

Na descrição do "Programa", enfatizo uma concentração no ato da exibição, ato que seria tematizado, no interior de cada um dos esquetes, através do que chamo de "formas de dar a ver". Essa concentração resulta do fato de que os acontecimentos captados resistem a uma "história" - seja numa dimensão diegética, ou seja, pressupondo um passado como "efeito de anterioridade" na narrativa, seja numa dimensão documental - os acontecimentos não são localizados historicamente, não se fixam como fatos ocorridos no momento da captação. No "Programa", os acontecimentos estão num presente absoluto, num regime literal que, resistindo à história, tampouco se abre para uma "duração". Nesse sentido, eles não reivindicam uma causalidade interna; existem para a câmera, e é a essa condição "externa" que remetem constantemente ${ }^{47}$. São situações que têm poder de demonstração, experimentos que sempre se poderiam reeditar - o estúdio de gravação é, para eles, um laboratório.

O fenômeno da exibição parece ocupar um lugar privilegiado na situação contemporânea, constituindo a face ativa daquilo que se tem freqüentemente designado como a era da "hegemonia das imagens". O "exibicionismo" seria a manifestação que permite a circulação daquelas representações de toda ordem que teriam suplantado a experiência sensível $^{48}$. Suspeito, entretanto, que o funcionamento desse mundo das imagens não depende tanto da ostentação do ato de mostrar, como do incentivo constante ao voyeurismo, da

\footnotetext{
${ }^{47}$ Ao tentar compreender o estatuto desses acontecimentos, deparei-me com uma passagem do texto de Eisenstein "Montagem de atrações", cujo objeto era o teatro. Acredito que, feitas as devidas mediações, a noção de "segmento figurativo" é interessante para se pensar o "Programa": "O meio que libera o teatro do jugo da 'figuração ilusionista' e da 'representação' - até agora decisivas, inevitáveis e unicamente possíveis - implica a montagem de 'coisas reais', ao mesmo tempo em que permite a inserção de 'segmentos figurativos' inteiros e de um enredo coerente, não mais como elementos suficientes e determinantes, mas como atração dotada de um grande efeito, conscientemente selecionada para uma proposta precisa." [EISENSTEIN, S. Montagem de atrações. In: XAVIER, Ismail (Org.). A experiência do cinema. Rio de Janeiro: Graal/ Embrafilmes, 1983, p. 191].

${ }^{48} \mathrm{O}$ debate em torno da "hegemonia das imagens", ultimamente um tanto banalizado, tem suas fontes mais rigorosas na história do pensamento moderno em autores como Walter Benjamin [no texto já citado "A obra de arte na era de sua reprodutibilidade técnica" e em Passagens. Belo Horizonte: Editora da UFMG/ São Paulo: Imprensa Oficial, 2006] e Adorno e Horkheimer [Dialética do esclarecimento. Rio de Janeiro: Jorge Zahar, 1985]. Para uma abordagem um pouco mais recente do debate, consultem-se as formulações de Guy Debord, principalmente em A sociedade do espetáculo [Rio de Janeiro: Contraponto, 1997].
} 
supervalorização daquele que vê. Trata-se de fortalecer uma ilusão de onipotência visual, uma ilusão, portanto, de transparência do mundo à vigilância dos sujeitos.

Por outro lado, alguns teóricos do cinema consideram que as primeiras manifestações explicitavam a própria capacidade de mostrar do novo meio ${ }^{49}$. Conforme esses autores, os filmes realizados até 1906 (o chamado primeiro cinema), destinados ao entretenimento popular, exploravam a exibição, incitando a curiosidade visual e apresentando pequenos eventos "em toda a sua atualidade" - o cinema, muitas vezes, exibindo suas próprias capacidades técnicas. Essa qualidade permaneceu central com o advento de um cinema propriamente modernista, que associou a ela um horizonte utópico - exibir era também descobrir um mundo em processo, passar a ver de modo diferente. No entanto, com o fortalecimento posterior do cinema narrativo, aquela qualidade seria desprestigiada em favor da construção ilusionista, onde o espectador, para o qual os atores não mais podiam olhar diretamente, tornava-se um voyeur ${ }^{50}$.

$\mathrm{Na}$ formulação do conceito de "cinema de atrações" em referência aos filmes feitos até 1906, Tom Gunning opõe, ao voyeurismo do cinema narrativo, o exibicionismo daquele primeiro cinema ${ }^{51}$. Conforme o autor, o cinema de atrações exibiria sua própria visibilidade,

\footnotetext{
${ }^{49} \mathrm{Cf}$. os textos reunidos na coletânea Early cinema: space - frame - narrative, editada por Thomas Elsaesser e Adam Barker [Londres: BFI Publishing, 1992].

${ }^{50}$ Vejam-se estas considerações de Christian Metz: "O filme é exibicionista e não ao mesmo tempo. Ou então há pelo menos vários exibicionismos e vários voyeurismos correspondentes [...]. O exibicionismo verdadeiro porta em si alguma coisa do triunfo e é sempre bilateral, na permuta dos fantasmas quando não na materialidade das ações: ele é da ordem do discurso, não da história, e repousa inteiramente sobre o jogo das identificações cruzadas, sobre o vai-e-vem assumido do $e u$ ao $t u$. [...] Se há triunfo em tais representações, é porque aquilo que exibem não é exatamente o exibido, mas, através dele, a exibição mesmo." E mais adiante: "O filme [no cinema clássico] não é exibicionista. Eu olho para ele, mas não ele para mim a olhá-lo. Contudo, sabe que olho. Mas faz que não sabe. Esta denegação fundamental foi o que orientou o cinema clássico pelas vias da 'história', que apagou-lhe sem cessar o suporte discursivo [...]". [História/discurso. Nota sobre dois voyeurismos. In: XAVIER, Ismail (Org.). Op. cit., 1983, p. 406-407].

${ }^{51}$ Cf. GUNNING, Tom. The cinema of attractions: early film, its spectator and the avant-garde. In: ELSAESSER, Thomas; BARKER, Adam (Ed.). Op. cit. - Gunning retoma o termo usado por Eisenstein no texto "Montagem de atrações", do qual reproduzi um pequeno trecho numa nota anterior [In: XAVIER, Ismail (Org.). Op. cit., 1983]. Entretanto, ele faz a ressalva, muito importante também aqui, de que o primeiro cinema era uma prática de entretenimento popular, ligada aos parques de diversões, feiras e espetáculos de vaudeville, e sua "heterogeneidade radical", seu "exibicionismo" e a "investida direta sobre o espectador" não diziam respeito a qualquer ideário de oposição à ilusão da absorção diegética. Nada que se
} 
estabelecendo um tipo particular de relação com o espectador em que sua atenção é solicitada diretamente. Os atores se dirigem aos espectadores, mostram-lhes coisas, piscam e pedem cumplicidade - não a cumplicidade da identificação narrativa, na qual o espectador deve abrir mão da atualidade da sua presença, mas uma cumplicidade relacionada à própria condição de visibilidade; os atores e frequentemente um showman que conduz a apresentação (narra, constrói efeitos sonoros e até reedita o filme) produzem estímulos de choque ou surpresa, que só se completam com a resposta do espectador. $\mathrm{O}$ cinema de atrações se dirige ao presente do momento da transmissão. Uma consciência da artificialidade dos estímulos também se evidencia nesse cinema: a imagem cinematográfica é assumidamente construída, mesmo quando se trata da apresentação de eventos "reais".

Acredito que o processo por que passamos atualmente, no que tange à visibilidade, se relaciona com uma expansão da ilusão narrativa característica do cinema clássico para todas as representações da vida ${ }^{52}$, o sujeito contemporâneo comportando-se como espectador identificado em tempo integral. Se esse argumento tiver alguma pertinência, poderemos considerar que a ostentação do ato de exibir tem papel secundário.

De todo modo, no "Programa", embora a referência ao primeiro cinema seja sugestiva - sobretudo ao conceito de "atração", que envolve, além dos aspectos já mencionados, uma variedade dos assuntos e a apresentação breve de acontecimentos fechados -, a explicitação das formas de dar a ver não parece prometer qualquer "novidade”. Dar a ver é uma espécie de exercício ativo sem "substância", exercício cuja aspiração realista não se liga à representação dos objetos (ou de sua lógica de articulação), mas à reiteração um tanto teimosa de suas formas. A mimese é o procedimento central do "Programa". Não a imitação transparente do cinema narrativo, mas a afinidade mimética entre a câmera e as coisas filmadas; mimese

aproxime do objetivo manifesto de "elevar o nível organizacional da vida cotidiana das massas" da proposta de Eisenstein [p. 187].

${ }^{52}$ Evidentemente não estou propondo que a "espetacularização da vida", seja ela associada ao exibicionismo ou ao voyeurismo, tenha resultado historicamente da matriz do cinema clássico. "O espetáculo não pode ser compreendido como o abuso de um mundo da visão, o produto das técnicas de difusão maciça das imagens. Ele é uma Weltanschauung que se tornou efetiva, materialmente traduzida. É uma visão de mundo que se objetivou." [DEBORD, Guy. Op. cit., p. 14]. 
opaca porque impede que o espectador "atravesse" as mediações do aparato. O trabalho procura a imanência às formas do mundo, e se diferencia delas porque a construção meticulosa acaba por produzir um excesso: as formalizações exibem acintosamente sua literalidade, e, quando bem-sucedidas, ganham uma qualidade clarividente.

O termo opacidade, por sinal, tendo sido utilizado algumas vezes neste texto, solicita um esclarecimento. Ele aparece ligado à "revelação do aparato", o que poderia levar à associação da minha posição, se não com o cinema de vanguarda dos anos 1920, com o cinema experimental dos anos 1960 e 70 e com as teorias do cinema como "dispositivo" (de autores franceses como Jean Louis Baudry e Christian Metz). Essas teorias propunham a crítica ideológica ao efeito-janela do cinema narrativo clássico - fundado justamente na "dissimulação da base técnica" - a partir da consideração das condições de produção, circulação e recepção dos filmes ${ }^{53}$. No cinema experimental ${ }^{54}$, por sua vez, materiais heterogêneos, enquadramentos inusuais, rupturas de continuidade e uma manipulação ostensiva (tanto dos recursos técnicos quanto dos materiais visuais e sonoros) poderiam fabricar imagens plasticamente eloqüentes que, apoiadas na desconstrução da identificação do espectador com os personagens e fatos da "história", se afirmassem como signos, elementos

\footnotetext{
53 “A especificidade cinematográfica se refere, pois, a um trabalho, isto é, a um processo de transformação. O que importa é saber se o trabalho está à mostra, se o consumo do produto provoca um efeito de conhecimento; ou se ele é dissimulado e, neste caso, o consumo do produto será evidentemente acompanhado de uma mais-valia ideológica. No plano prático, coloca-se a questão dos procedimentos pelos quais o trabalho pode efetivamente tornar-se legível em sua inscrição. Estes procedimentos devem obrigatoriamente levar a técnica cinematográfica a intervir. Mas, por outro lado, e em relação à primeira questão, pode-se perguntar se os instrumentos (a base técnica) produzem efeitos ideológicos específicos e se tais efeitos são determinados pela ideologia dominante; nesse caso, a dissimulação da base técnica também provocará um efeito ideológico determinado. Sua inscrição, sua manifestação como tal, deveria, pelo contrário, produzir um efeito de conhecimento, ao mesmo tempo atualização do processo do trabalho, denúncia da ideologia e crítica do idealismo". BAUDRY, Jean-Louis. Cinema: efeitos ideológicos produzidos pelo aparelho de base. In: XAVIER, I. (Org.). Op. cit., 1983, p. 386.

54 “Os filmes de Godard não apresentam mais aquele tipo de espetáculo cuja imagem se oferecia como uma transparência reveladora dos fatos - ele utiliza-se, de um modo crescente, de um universo visual heterogêneo, composto de diferentes materiais, e avança decididamente rumo à descontinuidade do cinemadiscurso. A câmara do cinema moderno não mais se esconde, mas participa abertamente do jogo de relações que dá estrutura aos filmes. Os atores não mais pretendem ignorar a presença do equipamento de filmagem e sua ação deixou de ser mise-en-scène tradicional. Agora, eles fazem o evento acontecer diante da câmera, de improviso, e encaram a objetiva dirigindo-se diretamente à platéia." XAVIER, Ismail. Op. cit., 2005, p. 141.
} 
de um discurso. A oposição opacidade/ transparência no interior desses movimentos se relaciona à oposição entre a "imagem-presença", dramático", de outro ${ }^{56}$.

No "Programa", acontece um "adensamento da imagem-som em sua imanência", para usar a expressão de Ismail Xavier ${ }^{57}$, mas sem que esse adensamento implique ganho de plasticidade: não há "interdição de sentido", mas tampouco há um olhar doador de sentidos particulares, autoral; não há rupturas de continuidade; não há manipulação dos enquadramentos; não há atenção ao pormenor, ao fragmento, ao detalhe. A revelação do aparato se dá sem que se pretenda uma relação com a "natureza do dispositivo", longe, portanto, da fórmula recorrente nas teorias das vanguardas e nas teorias do cinema moderno, para as quais "é da natureza do dispositivo que derivam os valores da arte" ${ }^{\text {.58 }}$ O aparato que se revela nesses vídeos é pura mecânica. O exercício é, como já se disse, ativo, mas sem "substância".

\footnotetext{
${ }^{55}$ Note-se que aqui o estatuto da imagem é oposto àquele que advém dos diagnósticos de certa literatura contemporânea que se declara herdeira da tradição crítica de Adorno e Horkheimer e, posteriormente, Debord. A imagem não é mistificação ou suplantação da experiência sensível, mas a própria linguagem do cinema, linguagem que, materialmente evidenciada, pode fazer, justamente, a denúncia das ideologias.

${ }^{56}$ Cf. XAVIER, Ismail. As aventuras do dispositivo (1978-2004). O discurso cinematográfico: opacidade e transparência. Op. cit., 2005. Embora, em favor do argumento, eu esteja aproximando as teorias do cinema como dispositivo ao cinema experimental dos anos 1960 e 1970, o próprio Christian Metz chama a atenção para o fato de que a desconstrução da identificação com os personagens, a que ele denomina "identificação secundária", pode levar ao fortalecimento de uma outra identificação: a identificação do espectador com o próprio "dispositivo" como fetiche (a identificação primária). Nesse sentido, o cinema experimental pode, a despeito de suas intenções libertárias, levar a um "esteticismo idealista". Ver a entrevista concedida pelo autor: "O dispositivo cinematográfico como instituição social" [In: XAVIER, I. (Org.). Op. cit., 1983].

${ }^{57}$ Op. cit., 2005.

${ }^{58}$ Idem, p. 203.
} 


\section{Referências bibliográficas}

ABBAGNANO, N. Dicionário de filosofia. São Paulo: Martins Fontes, 2000.

ADORNO, Theodor. Commitment. In: Aesthetics and politics. Londres: Verso, s/d.

Notas de literatura I. São Paulo: Duas Cidades/ Ed. 34, 2003.

Prismas: crítica cultural e sociedade. São Paulo: Ática, 2001.

Teoria estética. Lisboa: Edições 70, s/d.

; HORKHEIMER, Max. Dialética do esclarecimento. Rio de Janeiro: Jorge Zahar, 1985.

ARANTES, Otília Beatriz Fiori. Entrevista com Otília Beatriz Fiori Arantes. Rapsódia almanaque de filosofia e arte. São Paulo: Departamento de Filosofia da FFLCH-USP, maio de 2002.

ARGAN, G. C. Arquitetura e 'enciclopédia'. In: História da arte como história da cidade. São Paulo: Martins Fontes, 1998.

AUMONT, Jacques. As teorias dos cineastas. Campinas: Papirus, 2004.

et al. A estética do filme. Campinas: Papirus, 1995.

; MARIE, Michel. Dicionário teórico e crítico de cinema. Campinas: Papirus, 2003.

BARTHES, R. Mitologias. Rio de Janeiro: Difel, 2003.

BAUDRY, Jean-Louis. Cinema: efeitos ideológicos produzidos pelo aparelho de base. In: XAVIER, Ismail. (Org.). A experiência do cinema. Rio de Janeiro: Graal/ Embrafilmes, 1983. 
BENJAMIN, Walter. A obra de arte na era de sua reprodutibilidade técnica. In: Obras escolhidas: magia e técnica, arte e política. São Paulo: Brasiliense, 1994. . Passagens. Belo Horizonte: Editora da UFMG/ São Paulo: Imprensa Oficial, 2006.

BUCCI, Eugênio. A crítica de televisão. In: BUCCI, Eugênio; KEHL, Maria Rita. Videologias: ensaios sobre televisão. São Paulo: Boitempo, 2004.

DESCARTES, R. Discurso do método. In: Pensadores. São Paulo: Nova Cultural, 1996.

DEBORD, Guy. A sociedade do espetáculo. Rio de Janeiro: Contraponto, 1997.

DUBOIS, Phillipe. Cinema, vídeo, Godard. São Paulo: CosacNaify, 2004.

EISENSTEIN, S. A forma do filme. Rio de Janeiro: Jorge Zahar, 2002. . Montagem de atrações. In: XAVIER, I. (Org.). Experiência do cinema. Rio de Janeiro: Graal/ Embrafilmes, 1983.

O sentido do filme. Rio de Janeiro: Jorge Zahar, 2002.

FERRATER MORA, José. Diccionario de filosofía. Madri: Alianza Editorial, 1986.

FOUCAULT, Michel. A arqueologia do saber. $7^{\mathrm{a}}$ edição. Rio de Janeiro: Forense Universitária, 2004. . As palavras e as coisas. São Paulo: Martins Fontes, 2000.

GUNNING, Tom. The cinema of attractions: early film, its spectator, and the avant-garde. In: ELSAESSER, Thomas; BARKER, Adam (Ed.). Early cinema: space - frame narrative. Londres: BFI Publishing, 1992.

HABERMAS, Jürgen. Mudança estrutural da esfera pública: investigações quanto a uma categoria da sociedade burguesa. Rio de Janeiro: Tempo Brasileiro, 1984. 
KRACAUER, Siegfried. The mass ornament. Weimar essays. Cambridge-Massachusetts; Londres: Harvard University Press, 1995.

MACHADO, Arlindo. Máquina e imaginário: o desafio das poéticas tecnológicas. São Paulo: EDUSP, 1993.

. O vídeo e sua linguagem. In: Pré-cinemas e pós-cinemas. Campinas: Papirus, 1997.

METZ, Christian. História/discurso. Nota sobre dois voyeurismos. In: XAVIER, Ismail. A experiência do cinema. Rio de Janeiro: Graal/ Embrafilmes, 1983.

O dispositivo cinematográfico como instituição social. Entrevista. In: XAVIER, Ismail. A experiência do cinema. Rio de Janeiro: Graal/ Embrafilmes, 1983.

SAFATLE, Vladimir. A paixão do negativo: Lacan e a dialética. São Paulo: UNESP, 2006.

VAUGHAN, Dai. Let there be Lumière. In: ELSAESSER, Thomas; BARKER, Adam (Ed.). Early cinema: space - frame - narrative. Londres: BFI Publishing, 1992.

XAVIER, I. (Org.). A experiência do cinema. Rio de Janeiro: Graal/ Embrafilmes, 1983. O discurso cinematográfico: a opacidade e a transparência. $3^{a}$ edição. São Paulo: Paz e Terra, 2005. 